Ritrýnd grein birt 21. júní 2018

\title{
Staðsetning háskóla og menntabil í háskólamenntun
}

\author{
Dóroddur Bjarnason
}

\section{- Abstract Um höfund About the author}

Umtalsverður munur er á hlutfalli háskólamenntaðs fólks á höfuðborgarsvæðinu og utan pess. Detta menntabil skýrist að hluta til af fjölbreyttari atvinnumöguleikum háskólamenntaðs fólks á höfuðborgarsvæðinu en ýmsir aðrir efnahagslegir, félagslegir, menningarlegir og landfræðilegir pættir skipta par einnig máli. Pannig hafa rannsóknir sýnt að staðsetning háskóla getur haft veruleg áhrif á búsetu brautskráđra háskólanema. Í pessari rannsókn eru áhrif íslenskra háskóla á menntunarstig og menntabil einstakra landsvæða metin á grundvelli manntals og spurningakannana meðal 25-64 ára íbúa landsins. Niðurstöður sýna að 28\% íbúa höfuðborgarsvæðisins en 12-14\% íbúa annarra landshluta hafa lokið prófi frá háskólum í Reykjavík. Mikill meirihluti háskólamenntaðra landsmanna hefur lokið prófi frá Háskóla Îslands. Hlutfallið er hæst á höfuðborgarsvæðinu en lægst á Akureyri, par sem nánast jafn margir hafa lokið prófi frá Háskóla Íslands og Háskólanum á Akureyri. Á höfuðborgarsvæðinu og í öðrum péttbýliskjörnum í seilingarfjarlægð á Háskólinn í Reykjavík næstmesta hlutdeild í háskólamenntuðum íbúum en á norðursvæði landsins er hlutdeild Háskólans á Akureyri næstmest. Flestir brautskráđir nemendur háskólanna í Reykjavík og Háskólans á Bifröst eru búsettir á höfuðborgarsvæðinu en búseta nemenda annarra háskóla er dreifðari um landið. Brautskráđir nemendur Háskólans á Akureyri skiptast nokkuð jafnt milli höfuðborgarsvæðisins, Akureyrar og annarra landsvæða en rúmlega helmingur brautskráðra nemenda Landbúnaðarháskóla Íslands er að vonum búsettur utan péttbýlustu svæða landsins. Landsbyggðaháskólarnir útskrifa pannig nemendur sem eru mun líklegri til að búa utan höfuðborgarsvæðisins en áhrif peirra á menntunarstig einstakra landsvæða eru einkum bundin við áhrif Háskólans á Akureyri á Akureyri og annars staðar á norðanverðu landinu. Eigi að hækka menntunarstig í öllum landshlutum og draga úr menntabili milli Reykjavíkur og annarra landshluta parf að skilgreina slík markmið með skýrum hætti og ákveða hvort pað skuli vera hlutverk allra háskóla eða sérstakt verkefni peirra sem eru utan Reykjavíkur.

Efnisorð: Háskólar, menntunarstig, menntabil, landsvæði.

Á síðustu áratugum hefur orðið umbylting á starfsemi og skipulagi íslenskra háskóla. Margvíslegt nám hefur verið fært á háskólastig, háskólakennsla tekin upp í nýjum námsgreinum og meistaraog doktorsnám verið eftt til muna (Mennta- og menningarmálaráðuneytið, 2015a). Jafnframt hafa nýir háskólar verið stofnaðir, eldri sérskólar færðir á háskólastig, stofnanir sameinaðar og nöfnum einstakra háskóla ítrekað verið breytt. Nemendum við íslenska háskóla fjölgaði úr tæplega fimm púsund árið 1987 í tæplega tuttugu púsund árið 2013 en íslenskum háskólanemum erlendis fækkaði lítillega og hlutfall peirra af öllum háskólanemum lækkaði úr 35-45\% í 15-20\% (Mennta- og menningarmálaráđuneytið, 2015a). 
Með fjölgun háskóla var horfið frá aldargamalli stefnu um að byggja upp einn íslenskan háskóla fyrir alla pjóðina í Reykjavík (Bragi Guðmundsson, 2012; Guðmundur Hálfdanarson, 2011; Magnús Guðmundsson, 2011). Auk Listaháskóla Íslands og Háskólans í Reykjavík urðu til fjórir háskólar utan höfuðborgarsvæðisins pegar Háskólinn á Akureyri var stofnaður frá grunni og Samvinnuskólinn á Bifröst, Bændaskólinn á Hvanneyri og Búnaðarskólinn á Hólum voru færðir á háskólastig. Fram til ársins 1987 voru pannig engir nemendur við háskóla utan Reykjavíkur en árið 2014 voru peir um 2.500 talsins (Hagstofa Íslands, 2017a).

Dessi mikli vöxtur háskólastigsins byggðist ekki á markvissri, opinberri stefnu um uppbyggingu og skipulag háskólanáms á Íslandi (Gyða Jóhannsdóttir, 2008; Magnús Guðmundsson, 2011). I opinberri umræðu hefur sérstaklega verið gagnrýnt að byggðasjónarmiðum hafi verið blandað með óeðlilegum hætti í uppbyggingu háskólastigsins (sjá t.d. Börk Hansen, 2005; Jón Gunnar Grjetarsson, 1987; Magnús Guðmundsson, 2011; RúnarVilhjálmsson, 2005) og pví haldið fram að háskólar hafi verið stofnaðir líkt og „,refabú“ (Jón Bragi Bjarnason, 1989) eða jafnvel sprottið líkt og „,gorkúlur á mykjuskán“ (Dorkell Jóhannesson, 2004) i „hverju krummaskuði á Íslandi““ (Kári Stefánsson, 2011).

Á síðustu árum hefur mikið starf verið unnið við mat á árangri háskólastarfs í pví skyni að styrkja stefnumótun í málaflokknum. Pannig metur gæðaráð íslenskra háskóla gæði háskólagráđa, upplifun nemenda og stjórnsýslu rannsókna með reglubundnum hætti (Lög um háskóla nr. 63/2006; Rannís, 2017a, 2017b) og ítarlegt mat hefur verið lagt á árangur háskólanna í rannsóknum eins og hann kemur fram í birtum ritverkum og tilvitnunum til peirra á alpjóðlegum vettvangi (sjá t.d. Menntaog menningarmálaráđuneytið, 2015a; NordForsk, 2017). Áhrif einstakra háskóla á menntunarstig pjóðarinnar eða menntabil milli ólíkra landshluta hafa hins vegar ekki verið metin með fullnægjandi hætti.

\section{Uppbygging háskólamenntunar á Íslandi}

Uppbygging menntastofnana var snar páttur í uppbyggingu Reykjavíkur sem miðstöðvar íslensks pjóðlífs í sjálfstæðisbaráttu pjóđarinnar (Loftur Guttormsson, 2008). Pannig var Bessastaðaskóli fluttur til Reykjavíkur 1846 og ári síðar tók Prestaskólinn til starfa í húsnæði Lærða skólans í Reykjavík. Pá var Læknaskólinn stofnaður í Reykjavík 1876, Stýrimannaskólinn í Reykjavík árið 1890, Iðnskólinn í Reykjavík 1904, Verzlunarskóli Íslands 1905 og Kennaraskóli Íslands og Lagaskólinn árið 1908. Tildrög stofnunar Háskóla Íslands árið 1911 hafa verið rakin til hugmynda Jóns Sigurðssonar og félaga sumarið 1845 um stofnun pjóđskóla sem nægði pörfum pjóðarinnar, en frumvarp um Háskóla Íslands var pó ekki lagt fram á Alpingi fyrr en árið 1881 (Guðmundur Hálfdanarson, 2011).

Á sama tímabili var mikil áhersla lögð á eflingu grunnmenntunar um land allt og nauðsyn pess að ungt fólk gæti stundað hagnýtt nám í heimabyggð (Loftur Guttormsson, 2008). Kvennaskólar tóku til starfa í Reykjavík 1874, í Eyjafirði og Skagafirði 1877 og í Húnavatnssýslu 1879, og fyrsti gagnfræðaskóli landsins var stofnaður á Möðruvöllum í Eyjafirði árið 1880. Pá voru búnaðarskólar stofnaðir víða um land, meðal annars á Hólum í Hjaltadal 1882 og á Hvanneyri 1889. Jafnframt voru gerðar tilraunir með stofnun alpýðu- og lýðskóla að norrænni fyrirmynd og á fyrri hluta 20. aldar voru priggja vetra héraðsskólar á gagnfræðastigi stofnaðir í öllum landshlutum (Loftur Guttormsson, 2008).

Í lok 19. aldar lýsti Jón Dorkelsson (1891) mikilvægi pess að færa pungamiðju íslensks menntalífs og vísinda frá Kaupmannahöfn til Reykjavíkur með stofnun íslensks háskóla. Pannig yrði komið í veg fyrir pað manntjón sem Ísland hefði beðið af Hafnarferðum stúdenta, háskólamenntun myndi í auknum mæli miða að pörfum íslensks atvinnulífs, stjórnsýslu og menningar, og reglulegt stúdentalíf myndi skapa fjör og viðskipti í Reykjavík, sem árið 1891 taldi ríflega prjú púsund íbúa. Frá háskólanum í Reykjavík myndi pekking á sögu landsins, lögum og bókmenntum breiðast út meðal tæplega 72 púsund íbúa landsins. Auk pess yrðu lærðir menn pjóðlegri og betri Íslendingar, málinu yrði minni hætta búin af dönsku og landið sjálft myndi vaxa í augum hinna menntuðu pjóða. 
Háskóli Íslands varð að veruleika á hundrað ára ártíð Jóns Sigurðssonar, 17.júní 1911. Reykvíkingar voru pá orðnir um tólf púsund talsins og landsmenn allir um 86 púsund. Fyrstu áratugina var háskólinn lítill og veikburða og háskólinn í Kaupmannahöfn og aðrir erlendir háskólar gegndu áfram mikilvægu hlutverki í háskólamenntun pjóđarinnar (Guðmundur Hálfdanarson, 2011). Háskóli Íslands vann sér pó smám saman sess sem helsta menntastofnun landsins og eini háskóli Íslands fram til ársins 1971, pegar Kennaraskóli Íslands varð Kennaraháskóli Íslands. Forræði Háskóla Íslands í háskólamenntun pjóðarinnar var pó yfirgnæfandi fram undir lok síðustu aldar.

\section{Stofnun háskóla á Norðurlandi}

Á fyrstu áratugum 20. aldar voru vaxandi kröfur gerðar um eflingu bóknáms utan Reykjavíkur. Tillaga um stofnun menntaskóla Norður- og Austurlands var felld á Alpingi 1923 og að sögn varaði Bjarni Jónsson frá Vogi sérstaklega við pví að Norðlendingar myndu bráðlega heimta háskóla ef menntaskóli yrði stofnaður á Norðurlandi (Bragi Guðmundsson, 2012). Í trássi við synjun Alpingis stofnaði Jónas Jónsson frá Hriflu menntamálaráðherra til náms til stúdentsprófs við Gagnfræðaskóla Akureyrar með reglugerð 1927 og í framhaldi af pví var Menntaskólinn á Akureyri stofnaður með lögum árið 1930.

Forspá Bjarna frá Vogi rættist árið 1958 pegar Pórarinn Björnsson, skólameistari Menntaskólans á Akureyri, mun hafa lagt til að stofnaður yrði háskóli á Akureyri (Halldór Blöndal, 1986), og fjórum árum síðar skoraði Davíð Stefánsson frá Fagraskógi á bæjaryfirvöld að marka háskóla strax lóð í bæjarlandinu (Bragi Guðmundsson, 2012).Árið 1964 lögðu Ingvar Gíslason o.fl. fram pingsályktunartillögu um að stefnt skyldi að pví að háskóli tæki til starfa á Akureyri í náinni framtíð (Tillaga til pingsályktunar um framtíðarstaðsetningu skóla og eflingu Akureyrar sem skólabæjar, nr. 48/1964). Í framhaldi af pví voru svipaðar tillögur lagðar fram prisvar sinnum og vorið 1972 sampykkti Alpingi loks almennt orðaða pingsályktun um að ,,sérstaklega skuli að pví stefnt, að Akureyri verði efld sem skólabær og miðstöð mennta og vísinda utan höfuðborgarinnar" (Dingsályktun um dreifingu menntastofnana, áætlun um skólapörf og eflingu Akureyrar sem miðstöðvar mennta og vísinda utan höfuðborgarinnar, nr. 184/1972). Akureyringar voru pá orðnir á tólfta púsund talsins, eða litlu færri en Reykvíkingar höfðu verið við stofnun Háskóla Íslands í Reykjavík sextíu árum fyrr.

Nefnd sem Ingvar Gíslason menntamálaráðherra skipaði 1982 lagði til að stofnað yrði til náms á háskólastigi á Akureyri á vegum Háskóla Íslands (Menntamálaráđuneytið, 1984). Mjög skiptar skoðanir voru pó á pví máli og lýsti Ingvar Gíslason tillögunum sem „lágmarksbyrjunarstarfsemi“ sem tryggja yrði með lagasetningu svo „,forráðamenn Háskólans geti ekki vikið sér undan framkvæmdum af tylliástæðum, sem opinberir aðiljar eiga í pokahorninu“ (Ingvar Gíslason, 1985, bls. 7). Á ráđstefnu um háskólanám á Akureyri i júní 1985 lýsti rektor Háskóla Îslands raunar efasemdum um pörf á námi eftir stúdentspróf á Akureyri og skrifstofustjóri í menntamálaráðuneytinu lagði til að fjölmiðlatækni yrði notuð til háskólakennslu norður yfir heiðar (Á. M., 1985). Skólastjórar framhaldsskóla á Norðurlandi, fræðslustjóri og yfirlæknir á Fjórðungssjúkrahúsinu lögðu hins vegar punga áherslu á mikilvægi staðbundinnar háskólakennslu og lögðu ýmist til að háskóladeild, útibú frá Háskóla Íslands eða sjálfstæður háskóli yrði settur á fót á Akureyri hið fyrsta.

Stuðningur heimamanna við uppbyggingu háskólanáms á Akureyri endurspeglaði að mörgu leyti röksemdir sjálfstæðisbaráttunnar fyrir stofnun Háskóla Íslands (sjá t.d. Bjarna E. Guðleifsson, 1985; Braga Guðmundsson, 2012; G. S., 1985a, 1985b, Ingvar Gíslason, 1985;Vísindafélag Norðlendinga, 1985). Með stofnun háskólans myndi fleira ungt fólk á Norðurlandi sækja sér háskólamenntun, ekki síst ungar konur sem síður ættu heimangengt. Dá væri háskólafólk líklegt til að búa áfram og finna sér vinnu við hæfi par sem pað hefði stundað nám. Góð menntun og pekking myndi leiða af sér gott mannlíf og efla atvinnulíf á Norðurlandi.

Degar Sverrir Hermannsson tók við lyklunum að menntamálaráđuneytinu í október 1985 lýsti hann pví yfir að pað eina sem hann hefði pegar ákveðið væri að koma á fót háskóla á Akureyri (A. 
P. H., 1985). Atburðarásin sem fylgdi í kjölfarið líktist nokkuð aðdragandanum að stofnun Menntaskólans á Akureyri sextíu árum fyrr. Pannig var Háskólinn á Akureyri stofnaður með ákvörðun ráðherra og kennsla hófst haustið 1987. Alpingi (1988) sampykkti pá ráðstöfun hins vegar árið eftir með lögum um Háskólann á Akureyri.

\section{Umbylting háskólastigsins}

Í beinu framhaldi af stofnun Háskólans á Akureyri haustið 1987 voru einnig stofnaðir háskólar á vegum Verslunarráđs annars vegar og Samvinnuhreyfingarinnar hins vegar, en lítil opinber umræða varð um pau helmingaskipti. Í ávarpi við setningu Tölvuháskóla Verzlunarskóla Íslands í janúar 1988 fagnaði Birgir Ísleifur Gunnarsson menntamálaráðherra aukinni fjölbreytni háskólanáms og boðaði samræmda löggjöf um háskólastigið (Árni Sæberg, 1988). Í apríl 1988 veitti ráðherra Samvinnuskólanum á Bifröst heimild til að verða Samvinnuháskólinn á Bifröst og hófst kennsla um haustið.

Heildarlöggjöf um háskólastigið var pó ekki sett fyrr en í desember 1997 og fékk ráðherra menntamála pá víðtæka heimild til að veita nýjum ríkisreknum og einkareknum háskólum starfsleyfi (Lög um háskóla nr. 136/1997). Næsta áratuginn mótaðist núverandi stofnanaumgjörð háskólastigsins smám saman, án skýrrar opinberrar stefnu í peim efnum (Gyða Jóhannsdóttir, 2008; Magnús Guðmundsson, 2011). Árið 1998 var Viðskiptaháskólinn í Reykjavík stofnsettur á grunni Tölvuháskólans, en nafni viðskiptaháskólans var breytt í Háskólinn í Reykjavík árið 2000. Sama ár var nafni Samvinnuháskólans hins vegar breytt í Viðskiptaháskólann á Bifröst, og hann varð svo Háskólinn á Bifröst árið 2004. Árið 2001 var Listaháskóli Îslands stofnaður á grunni eldri listaskóla í Reykjavík. Bændaskólinn á Hvanneyri var einnig færður á háskólastig árið 2001, en hann varð Landbúnaðarháskóli Íslands árið 2005 með samruna við Rannsóknastofnun landbúnaðarins og Garðyrkjuskóla ríkisins. Árið 2002 varð Tækniskólinn í Reykjavík að Tækniháskóla Íslands en sameinaðist svo Háskólanum í Reykjavík árið 2005. Árið 2003 fékk Búnaðarskólinn á Hólum heimild til að starfa sem háskólastofnun, en hann var formlega gerður að Háskólanum á Hólum árið 2007. Árið 2006 tók Háskólasetur Vestfjarða til starfa og árið 2007 var Keilir stofnaður í Reykjanesbæ. Dessari hrinu breytinga lauk með pví að Kennaraháskóli Íslands var sameinaður Háskóla Íslands árið 2008.

Frá árinu 2008 hafa ítrekað komið fram hugmyndir um frekari sameiningu háskóla. Árið 2009 lagði nefnd erlendra sérfræðinga pannig til að allir opinberu háskólarnir yrðu sameinaðir Háskóla Íslands og hinir einkareknu Listaháskóli Íslands og Háskólinn á Bifröst yrðu sameinađir Háskólanum í Reykjavík. Nefndin lagði jafnframt til að háskólarnir tveir myndu „eftir pörfum“ (e. as necessary) halda úti svæðisbundnum útibúum (Mennta- og menningarmálaráðuneytið, 2009a, bls. 19) en í íslenskri pýđingu stjórnvalda breyttist pessi ráđlegging pó efnislega pannig að „háskólarnir tveir æettu að halda í landsbyggðaútibúin sem nauðsynlegan hluta starfseminnar" (Mennta- og menningarmálaráđuneytið 2009b, bls. 4).

Pótt hugmyndir hafi komið upp um sameiningu HÍ og HR (Orri Páll Ormarsson, 2013; RÚV, 2009; S. H.Á., 2009) hefur peim ekki verið fylgt eftir. Par virðast einkum ráða mismunandi rekstrarform, ólíkur uppruni háskólanna og stuðningur starfsmanna og stjórnmálamanna við sjálfstæði Háskólans í Reykjavík (Ritstjórn, 2009; RÚV, 2013a, 2013b). Ekki hefur heldur verið rætt af mikilli alvöru um sameiningu Háskólans á Akureyri og annarra háskóla, og kunna par að skipta máli atriði á borð við langa baráttu Norðlendinga fyrir sjálfstæðum háskóla (Bragi Guðmundsson, 2012), andstaða háskólayfirvalda (sjá t.d. Háskólaráð HA, 2009) og pólitískur stuðningur við sjálfstæði Háskólans á Akureyri á vettvangi sveitarstjórna og landsmála (sjá t.d. B. P., 2014; Dingskjal nr. 150/2011-2012. Fyrirspurn til mennta- og menningarmálaráðherra um sjálfstæði Háskólans á Akureyri; Eyping, 2011).

Á síðustu árum hefur hins vegar verið skoðað af talsverðri alvöru að sameina sjálfseignarstofnanirnar Háskólann á Bifröst og Háskólann í Reykjavík annars vegar (D. J. og S. H. A., 2010) og ríkisháskólana Háskóla Íslands og Landbúnaðarháskóla Íslands á Hvanneyri hins vegar (RÚVV, 2013c). Jafnframt hefur sameining Háskólans á Hólum, Háskólans á Bifröst og Landbúnaðarháskólans nýlega verið 
skoðuð (Mennta- og menningarmálaráðuneytið, 2015b). Slíkar hugmyndir hafa notið stuðnings yfirvalda menntamála en hafa í öllum tilvikum strandað á andstöđu pingmanna, sveitarstjórna og íbúa á svæðum par sem litlir, sjálfstæðir háskólar starfa (RÚV, 2014, 2015; Skessuhorn, 2013, 2014; Örn Arnarson, 2010).

Tillögur um sameiningar íslenskra háskóla byggjast að mestu á hugmyndum um fjárhagslega og fræðilega stærðarhagkvæmni og peirri tilfinningu að sjö háskólar séu óeðlilega margir fyrir litla pjóð (sjá t.d. Börk Hansen 2005; Inga FreyVilhjálmsson, 2013; Kára Stefánsson, 2011; Magnús Guðmundsson, 2011; Dorgerði Katrínu Gunnarsdóttur 2012). Á hinn bóginn hefur andstaða við slíkar tillögur einkum byggst á hugmyndum um mikilvægi sjálfstæðra háskóla fyrir atvinnu- og menntunarstig á viðkomandi svæðum og peirri trú að eftir sameiningu yrði starfsemi landsbyggðaútibúa fljótlega skipulögð eftir pörfum höfuðstöðvanna fremur en sem nauðsynlegur hluti sameinaðra háskóla (sjá t.d. Ingibjörgu Einarsdóttur, 2010; Jón Bjarnason, 2013; Magnús B. Jónsson, 2013; Sindra Sigurgeirsson, 2013; Skagfirðing 2012). Fræðilegar rannsóknir á svæðisbundnum áhrifum sjálfstæðra háskóla á menntabil hafa hins vegar ekki gegnt veigamiklu hlutverki í umræum um æskilega mennta- og byggðastefnu hér á landi

\section{Svæðisbundin áhrif háskóla}

Hátt hlutfall háskólamenntaðra íbúa stuðlar að próttmiklu atvinnulífi, öflugri pjónustu og fjölbreyttu samfélagi (Chatterton, 2000; Corcoran, Faggian og McCann, 2010; Gunasekara, 2006; Winters, 2011), en slík samfélög draga líka að sér háskólamenntað fólk (Abel og Deitz, 2012; Blackwell, Cobb og Weinberg, 2002; Gottlieb og Joseph, 2006; Waldorf, 2009). Dótt framboð starfa fyrir háskólamenntað fólk ráđist til skemmri tíma af vinnumarkaði einstakra svæða getur hátt menntunarstig pví til lengri tíma litið stuðlað að nýsköpun í atvinnulífi og aukið samkeppnishæfni peirrar atvinnustarfsemi sem pegar er til staðar (Ingi Rúnar Eðvarðsson, 2014). Í smærri samfélögum sem byggst hafa á einhæfum og hnignandi frumframleiðslugreinum getur hins vegar myndast ákveðinn vítahringur með lágu menntunarstigi og skorti á störfum fyrir háskólamenntað fólk (Anna Guðrún Edvardsdóttir, 2016; Dóroddur Bjarnason o.fl., 2016). Dannig getur jafnvel reynst erfitt að finna háskólamenntað fólk til peirra tiltölulega fáu starfa sem pó eru til staðar í dreifðari byggðum (Dóroddur Bjarnason og Ingi Rúnar Eðvarðsson, 2017).

Á undanförnum áratugum hefur háskólamenntun aukist bæði meðal peirra hópa sem áđur fyrr sóttu sér helst slíka menntun og hinna sem ólíklegri voru til pess. Hins vegar er misjafnt hvaða áhrif pessi próun hefur haft á menntabil milli hópa. Menntasókn kvenna hefur aukist hraðar en karla og víðast hvar í Evrópu ljúka fleiri konur en karlar nú háskólaprófi (Klesment og van Bavel, 2017). Frá síðustu aldamótum hefur hlutfall háskólamenntaðra kvenna pannig hækkað hraðar en karla á Íslandi og bilið pví aukist jafnt og pétt konum í hag (Mennta- og menningarmálaráđuneytið, 2015a). Hins vegar hefur menntabil eftir páttum á borð við kynpátt eða stéttarstöðu foreldra víða staðið í stað eða jafnvel aukist pótt menntunarstig allra hópa fari hækkandi (Gillborn, Demack, Rollock og Warmington, 2017; Liu, Green og Pensiero, 2016).

Með sama hætti hefur hlutfall háskólamenntaðra í dreifbýli víða hækkað án pess að menntabilið milli péttbýlis og dreifbýlis hafi endilega minnkað (sjá t.d. Liu o.fl., 2016; Maiga, 1983; Scott, Menzies, Chenard og Spence, 2013; Tam og Jiang, 2015). Dótt hlutfall háskólamenntaðra íbúa íslenskra landsbyggða hafi hækkað umtalsvert á síðustu árum er hlutfall háskólamenntaðra með sama hætti mun hærra á höfuðborgarsvæðinu en utan pess (Mennta- og menningarmálaráðuneytið, 2015a). Detta menntabil milli péttbýlis og dreifbýlis kann að hluta að skýrast af færri tækifærum til háskólamenntunar en að hluta af færri atvinnutækifærum fyrir háskólamenntað fólk.

Víða um heim hafa háskólar og útbú peirra verið stofnuð í peim tilgangi að hækka menntunarstig og auka fjölbreytni í atvinnulífi á svæðum sem hafa átt undir högg að sækja (Anderssen, Quigley og Wilhelmson, 2004, Anna Guðrún Edvardsdóttir, 2016; Arbo og Eskelinen, 2003; Frenette, 2009; Lehmann, Christensen, Thrane og Jorgensen, 2009; Tomaney og Wray, 2011). Dannig var stofnun 
svæðisbundinna háskóla páttur í opinberri byggðastefnu á Norðurlöndum á sjöunda og áttunda áratug síðustu aldar (Arbo og Eskelinen, 2003; Lehmann o.fl., 2009; Nilsson, 2006) og 1 tillögu til pingsályktunar um stofnun háskóla á Akureyri árið 1964 var sérstaklega vísað til stefnu Norðmanna í pessu sambandi (Alpingi, 1964). Í Svípjóð hefur verið sýnt fram á umtalsverð efnahagsleg áhrif slíkra svæðisbundinna aðgerða í háskólamálum (Anderssen o.fl., 2004, 2009). Um helmingur áhrifanna er innan 20 km fjarlægðar frá nýjum háskólum og um 75\% innan 100 km fjarlægðar.Á Íslandi hefur með svipuðum hætti verið sýnt fram á veruleg efnahagsleg áhrif af umsvifum Háskólans á Bifröst og Landbúnaðarháskóla Íslands á efnahagslíf og rekstur sveitarfélagsins Borgarbyggðar í Borgarfirði (Kolfinna Jóhannesdóttir og Vífill Karlsson, 2010;Vífill Karlsson og Magnús B. Jónsson, 2013).

Háskólar stuðla að hærra menntunarstigi á nærsvæðum sínum með ýmsum hætti, svo sem með menntun heimamanna, stúdentum sem ílengjast eftir útskrift og háskólamenntuðu starfffólki við háskólana og tengda starfsemi (Abel og Deitz, 2012; Anna Guðrún Edvardsdóttir, 2016; Gottlieb og Fogarty, 2003; Kolfinna Jóhannesdóttir og Vífill Karlsson, 2010; Nilsson, 2006).Víða um heim hafa rannsóknir sýnt að meirihluti peirra sem stunda háskólanám í heimabyggð verður par um kyrrt en minnihluti peirra sem fara til háskólanáms utan heimabyggðar snýr aftur heim að námi loknu (Blackwell o.fl., 2002; Corcoran o.fl., 2010; Haapanen og Tervo, 2012; Hoare og Corver, 2010).

Talsverður munur er á upptökusvæðum háskóla í Reykjavík og utan höfuðborgarsvæðisins. Pannig voru 69\% nemenda Háskóla Íslands (HÍ) af höfuðborgarsvæðinu og 11\% til viðbótar úr nágrannabyggðarlögum pess á tímabilinu 1991-2015 (Dóroddur Bjarnason, Ingi Rúnar Eðvarðsson, Ingólfur Arnarson, Skúli Skúlason og Kolbrún Ósk Baldursdóttir, 2016).Á sama tímabili voru 24\% nemenda Háskólans á Akureyri (HA) af höfuðborgarsvæðinu en 29\% frá Akureyri og 8\% til viðbótar annars staðar úr Eyjafirði. Hins vegar voru 57\% nemenda Háskólans á Bifröst (HB) og 43\% nemenda Háskólans á Hólum (HH) af höfuðborgarsvæðinu og aðeins 7-8\% peirra voru af nærsvæðum háskólanna á sunnanverðu Vesturlandi annars vegar og Norðurlandi vestra hins vegar. Degar litið er til samsetningar nemendahópsins einkennast pessir landsbyggðaháskólar pví af meiri breidd í uppruna nemenda og mun lægra hlutfalli heimafólks en stærri háskólarnir.

Á síðustu árum hefur í sívaxandi mæli verið litið til möguleika fjarnáms við að veita háskólamenntun í heimabyggð (Chawinga og Zozie, 2016; Ingi Rúnar Eðvarðsson, 2001; Muhirwa, 2012; OECD, 2015; Rennie, Jóhannesdóttir og Kristinsdóttir, 2011; Tomaney og Wray, 2011; Póroddur Barnason og Ingi Rúnar Eðvarðsson, 2017; Duríður J. Jóhannsdóttir, 2010). Dótt fjarnám hafi í upphafi byggst á póstsendingum og síðar sjónvarpsútsendingum hafa tækniframfarir nú gert fjarnemum kleift að horfa á upptökur fyrirlestra, taka pátt í umræðuhópum á netinu og vinna í rauntíma að verkefnum með samnemendum nær og fjær (Póroddur Bjarnason og Brynhildur Dórarinsdóttir, 2018). Dessar tækniframfarir hafa raunar gert muninn á staðarnemum og fjarnemum sífellt óljósari og nemendur á nærsvæðum háskóla nýta sér í vaxandi mæli pann sveigjanleika í tíma og rúmi sem felst í fjarnámstækninni (Anna Guðrún Edvardsdóttir, 2016; Duríður J. Jóhannsdóttir, 2010).

Á Íslandi er mikill munur á búsetu brautskráđra háskólanema eftir pví hvort peir purftu að flytja búferlum vegna háskólanáms eða ekki. Fjarnemar í landsbyggðunum eru hins vegar álíka líklegir til að búa áfram í heimabyggð og nemendur á höfuðborgarsvæðinu. Um $84 \%$ nemenda af höfuðborgarsvæðinu voru enn búsettir par fimm árum eftir grunnnám við HÍ, staðar- eða fjarnám við HB eða fjarnám við HA (Bóroddur Bjarnason o.fl. 2016). Hins vegar sneri aðeins um helmingur nemenda af höfuðborgarsvæðinu aftur að loknu staðarnámi við HA. Til samanburðar voru 69\% nemenda frá Akureyri búsettir í heimabyggð fimm árum eftir útskrift frá HA en aðeins 31\% peirra Akureyringa sem luku námi frá HÍ eða HB. Meðal nemenda af sunnanverðu Vesturlandi bjuggu 89\% fjarnema við HA í heimabyggð fimm árum eftir útskrift, um helmingur peirra sem stunduðu nám við $\mathrm{HB}$, 40\% peirra sem útskrifuðust frá HÍ og 31\% peirra sem luku staðarnámi við HA. Aðeins um priðjungur háskólanema af öðrum landsvæðum var enn í heimabyggð fimm árum eftir útskrift frá HÍ eða úr staðarnámi við HA eða HB. 


\section{Viðfangsefni rannsóknarinnar}

Í pessari rannsókn verða áhrif íslenskra og erlendra háskóla á menntunarstig einstakra svæða metin á grundvelli opinberra gagna og spurningakannana. Gera parf greinarmun á mikilvægi einstakra landsvæða fyrir háskólana annars vegar og mikilvægi einstakra háskóla fyrir landsvæðin hins vegar. Dannig getur til dæmis fámennt landsvæði skipt litlu máli sem búsetu- og atvinnukostur fyrir alla brautskráđa nemendur frá stórum háskóla en flestir háskólamenntaðir íbúar pess landsvæðis engu að síður verið brautskráđir frá peim háskóla. Á hinn bóginn getur tiltekið landsvæði skipt afar miklu máli fyrir alla brautskráđa nemendur lítils háskóla en peir samt verið mjög lágt hlutfall háskólamenntaðra íbúa pess svæðis. Í eftirfarandi greiningu verða áhrifasvæði háskólanna metin með prennum hætti.

Í fyrsta lagi verður litið á búsetu brautskráðra nemenda sem ákveðinn mælikvarða á staðbundin áhrif háskólanna. Búast má við pví að hátt hlutfall brautskráđra nemenda háskólanna í Reykjavík búi á höfuðborgarsvæðinu eða í seilingarfjarlægð frá pví og að tiltölulega hátt hlutfall brautskráðra nemenda Háskólans á Akureyri búi á Akureyri eđa annars staðar á norðursvæði landsins. Jafnframt má búast við pví að hátt hlutfall brautskráðra nemenda Háskólans á Bifröst búi á Vesturlandi, annars staðar á suðvestursvæði landsins eða á höfuðborgarsvæðinu og Háskólans á Hólum í Skagafirði eða annars staðar á norðursvæði landsins. Á hinn bóginn má búast við pví að brautskráđir nemendur Landbúnaðarháskóla Íslands dreifist um allt land og búi að stórum hluta utan péttbýlis.

Í öðru lagi verður litið á upprunastofnanir háskólamenntaðra íbúa hvers landsvæðis sem mælikvarða á mikilvægi einstakra háskóla fyrir háskólamenntun á viðkomandi svæði. Búast má við pví að yfirgnæfandi meirihluti háskólamenntaðra íbúa á höfuðborgarsvæðinu sé brautskráđur frá háskólunum í Reykjavík. Jafnframt má búast við pví að brautskráđir nemendur frá Háskólanum á Akureyri séu umtalsverður hluti háskólamenntaðra íbúa á Akureyri og e.t.v. á norðursvæði landsins.Vegna smæðar háskólanna á Bifröst og Hólum og Landbúnađarháskóla Íslands er hins vegar ólíklegt að peir hafi haft veruleg áhrif á samsetningu háskólamenntaðra íbúa á stærri landsvæðum.

Í priðja lagi má bera saman upplýsingar um menntunarstig einstakra landshluta samkvæmt Hagstofu Íslands og hlutdeild háskólanna í háskólamenntuðum íbúum peirra samkvæmt könnunum til að áætla áhrif hvers háskóla á menntabil milli landshluta. Búast má við pví að búseta brautskráđra nemenda frá háskólunum í Reykjavík skýri að verulegu leyti menntabil milli höfuðborgarsvæðisins og annarra landshluta. Með sama hætti má vera að búseta brautskráđra nemenda frá Háskólanum á Akureyri skýri að verulegu leyti hærra menntunarstig á Akureyri en í öðrum landshlutum. Hins vegar er einnig hugsanlegt að fjölbreyttara atvinnulíf og samfélag dragi brautskráđa nemendur frá öðrum háskólum í ríkari mæli til Akureyrar en annarra landsbyggða. Ólíklegt er að minni háskólarnir hafi veruleg áhrif á menntabil milli landshluta.

\section{Aðferð}

\section{Söfnun gagna}

Dessi rannsókn er hluti rannsóknarverkefnisins Svæðisbundin áhrif háskóla sem unnið var með styrk frá Byggðarannsóknasjóði. Gögnin byggjast annars vegar á manntali Hagstofu Íslands árið 2011 og hins vegar á svörum við spurningum sem lagðar voru fyrir Viðhorfahóp Gallup á tímabilinu 12. júní-25. október 2016.Viðhorfahópurinn samanstendur af um 22.000 einstaklingum 18 ára og eldri sem valdir eru með tilviljunaraðferð úr pjóðskrá.Vikulega er safnað um 800 svörum á netinu úr um pað bil 1.400 manna úrtaki og er svarhlutfall pannig um 55-60\%.

Í spurningavögnunum er spurt um margvísleg efni en vegna pessarar rannsóknar var bætt við einni bakgrunnsspurningu um menntun. Peir svarendur sem sögðust hafa lokið háskólaprófi fengu viðbótarspurninguna „Frá hvaða háskóla hefur pú lokið námi? (Vinsamlegast merktu við alla viðeig- 
andi svarkosti)“. Í svarkostum voru allir starfandi íslenskir háskólar taldir upp auk svarmöguleikans „Erlendum háskóla“ og opna svarmöguleikans „Öðrum íslenskum háskóla, hvaða?“ par sem svarendur gátu skrifað inn svar. Jafnframt gátu svarendur sleppt bví að nefna háskóla.

Alls fékkst 11.881 gilt svar. Par af sögðust 463 mest hafa lokið diplómaprófi, 2.885 höfðu mest lokið bakkalárprófi, 1.931 meistaraprófi eða sambærilegri gráđu og 177 doktorsprófi, eða samtals 5.456 einstaklingar með háskólapróf. Samtals vildu 437 ekki gefa upp nafn háskóla eða skrifuðu inn nöfn annarra skóla. Einkum var par um að ræða svarendur sem lokið höfðu prófi frá Kennaraháskóla Íslands fyrir sameiningu hans við Háskóla Íslands eða Tækniháskólanum fyrir sameiningu hans við Háskólann í Reykjavík. Đau svör voru endurkóðuð sem núverandi háskóli. Einnig voru erlendir háskólar nefndir í nokkrum tilvikum og voru pau svör endurkóðuð í samræmi við pað. Loks nefndu nokkrir svarendur skóla á framhaldsskólastigi eða sérskóla sem síðar voru færðir á háskólastig. Endanlegur fjöldi svarenda með háskólapróf frá hinum sjö starfandi íslensku háskólum eða erlendum háskólum taldist pví vera 5.304 einstaklingar.

\section{Skilgreiningar}

Tafla 1 sýnir fjölda íbúa á aldrinum 25-64 ára á einstökum landsvæðum samkvæmt manntalinu 2011 (Hagstofa Íslands 2017b) og fjölda svarenda í Gallup-könnun 2016. Talningarsvæði Hagstofunnar voru notuð sem grunnur fyrir svæðaskiptingu landsins. Pannig var höfuðborgarsvæðið notað óbreytt (7.033 svör) og Akureyri skilgreind sem eitt svæði í samræmi við talningarsvæði manntalsins (913 svör).

Í pessari rannsókn beinist athyglin sérstaklega að péttbýlissvæðum (e. exurban regions) í næsta nágrenni höfuðborgarsvæðisins, en talningarsvæði manntalsins á suðvestursvæði landsins endurspegla pau ekki fullkomlega. Í manntalinu eru Akranes og Hvalfjarðarsveit pannig skilgreind sem eitt talningarsvæði en Borgarbyggð ásamt öllum byggðarlögum á Snæfellsnesi og í Dalasýslu talin til Vesturlands norðan Skarðsheiðar. Á Suðurlandi er Árborg skilgreind sem sérstakt talningarsvæði en öll önnur byggðarlög á vestanverðu Suðurlandi teljast til Árnessýslu án Árborgar. Í eftirfarandi greiningu er hugtakið „SV-péttbýli““ notað um talningarsvæði manntalsins í Árborg, á Suðurnesjum og Akranesi og Hvalfjarðarsveit sem tiltekna tegund byggðar 1.343 svör), en hafa verður í huga að sú skilgreining fellur ekki fullkomlega að pví landsvæði sem sem stundum hefur verið nefnt „Suðvestursvæðið“, „Hvítársvæðið“ eða jafnvel „Stórhöfuðborgarsvæðið“.

Æskilegt hefði verið að skilgreina önnur svæði landsins nákvæmlega pannig að hægt væri að skoða áhrif einstakra háskóla á nærsvæðum minni háskólanna í Borgarfirði og Skagafirði. Úrtaksstærð könnunarinnar leyfði ekki svo nákvæma skiptingu pótt í greiningunni sé litið til vísbendinga um hlut minni háskólanna í heimabyggð. Pess í stað er í megindráttum byggt á skiptingu manntalsins 2011 í suðursvæði og norðursvæði, að SV-péttbýli og Akureyri undanskildum. Til „Suðursvæðis “ telst pannig Vesturland norðan Skarðsheiðar og Suðurland án Árborgar (952 svör). Dar af voru 211 pátttakendur af nærsvæði Bifrastar og Hvanneyrar í Borgarfirði og takmarkar pað möguleika á greiningu að aðeins 78 peirra höfðu lokið háskólaprófi. Til „Norðursvæðis“ teljast hins vegar Vestfirðir, Austurland og Norðurland án Akureyrar (1.640 svör). Par af voru 163 pátttakendur af nærsvæði Hóla í Skagafirði, og höfðu aðeins 53 peirra lokið háskólaprófi.

Eins og sjá má af töflu 1 höfðu 39\% íbúa á pessum aldri á höfuðborgarsvæðinu lokið háskólaprófi samkvæmt manntalinu, samanborið við 20-22\% íbúa á sama aldri í SV-péttbýli, á norðursvæði og suðursvæði. Akureyri er nálægt pví að vera miðja vegu par á milli par sem 31\% íbúanna var með háskólapróf. Hlutfall háskólamenntaðra er hærra í úrtaki Gallup en samkvæmt manntalinu, en landshlutamunur kemur fram með mjög svipuðum hætti î báðum gagnasöfnum. Á höfuðborgarsvæðinu er hlutfallið í könnuninni 1,6 sinnum hærra en í manntalinu, 1,7 sinnum hærra á Akureyri og 1,6-1,8 sinnum hærra í SV-péttbýli, á suðursvæði og norðursvæði. 
Tafla 1. Háskólamenntun 25 til 64 ára samkvæmt manntali 2011 og Gallup 2015

\begin{tabular}{lrrrrc}
\hline & (M) MANNTAL 2011 & (G) GALLUP 2015 & \\
& Fjöldi & Hlutfall & Fjöldi & Hlutfall & G/M \\
\hline Höfuðborgarsvæði & $\mathbf{1 0 5 . 5 5 3}$ & $\mathbf{3 9 \%}$ & $\mathbf{7 . 0 3 3}$ & $\mathbf{5 4 \%}$ & $\mathbf{1 , 4}$ \\
Reykjavík & 62.836 & $40 \%$ & 4.002 & $56 \%$ & 1,4 \\
Nágrannasveitarfélög & 42.717 & $38 \%$ & 3.031 & $51 \%$ & 1,3 \\
SV-péttbýli & $\mathbf{1 8 . 1 9 4}$ & $\mathbf{2 0 \%}$ & $\mathbf{1 . 3 4 3}$ & $\mathbf{3 1 \%}$ & $\mathbf{1 , 6}$ \\
Suðurnes & 10.863 & $17 \%$ & 649 & $31 \%$ & 1,8 \\
Akranes og Hvalfjarðarsveit & 3.535 & $23 \%$ & 298 & $32 \%$ & 1,4 \\
Árborg & 3.796 & $24 \%$ & 396 & $30 \%$ & 1,3 \\
Suðursvæði annað & $\mathbf{1 3 . 0 4 9}$ & $\mathbf{2 1 \%}$ & $\mathbf{9 5 2}$ & $\mathbf{3 2 \%}$ & $\mathbf{1 , 5}$ \\
Vesturland norðan Skarðsheiðar & 4.181 & $22 \%$ & 353 & $32 \%$ & 1,5 \\
- Dar af Borgarfjörður & --- & --- & 211 & $37 \%$ & --- \\
Árnessýsla án Árborgar & 3.677 & $21 \%$ & 212 & $30 \%$ & 1,4 \\
Vestmannaeyjar & 2.054 & $20 \%$ & 152 & $36 \%$ & 1,8 \\
Skaftafells- og Rangárvallasýslur & 3.137 & $19 \%$ & 235 & $30 \%$ & 1,6 \\
Akureyri & $\mathbf{8 . 7 9 8}$ & $\mathbf{3 1 \%}$ & $\mathbf{9 1 3}$ & $\mathbf{4 1 \%}$ & $\mathbf{1 , 3}$ \\
Norðursvæði annað & $\mathbf{1 7 . 4 5 4}$ & $\mathbf{2 2 \%}$ & $\mathbf{1 . 6 4 0}$ & $\mathbf{3 0 \%}$ & $\mathbf{1 , 4}$ \\
Vestfirðir & 3.456 & $21 \%$ & 339 & $31 \%$ & 1,5 \\
Norðurland vestra & 3.491 & $22 \%$ & 303 & $30 \%$ & 1,4 \\
- Dar af Skagafjörður & -- & --- & 163 & $33 \%$ & 1 \\
Eyjafjörður & 3.018 & $21 \%$ & 275 & $28 \%$ & 1,3 \\
Dingeyjarsýslur austan Eyjafjarðar & 2.353 & $21 \%$ & 229 & $31 \%$ & 1,5 \\
Austurland & 5.136 & $23 \%$ & 494 & $29 \%$ & 1,3 \\
\hline
\end{tabular}

Háskólamenntaðir svarendur endurspegli hóp háskólamenntaðra íbúa á hverju landsvæði og pannig megi nota gögnin til að áætla hlut einstakra háskóla í háskólamenntun á viðkomandi svæði. Gögnin voru vegin til að endurspegla mannfjölda á einstökum landsvæðum og reyndist hlutfall höfuðborgarsvæðisins af öllum háskólamenntuðum landsmönnum á aldrinum 25-64 ára pá vera 76\% samkvæmt bæði úrtaki Gallup og manntali Hagstofu Íslands (2017b).

Niðurstöður eru sýndar fyrir einstaka háskóla og yfirflokka peirra. Til yfirflokksins Háskólar í Reykjavík teljast Háskóli Íslands (HÍ) Háskólinn í Reykjavík (HR) og Listaháskóli Íslands (LHÍ). Til yfirflokksins Háskólar utan Reykjavíkur teljast Landbúnaðarháskóli Íslands (LBHÍ), Háskólinn á Bifröst (HB), Háskólinn á Hólum (HH) og Háskólinn á Akureyri (HA). Loks eru niðurstöður fyrir erlenda háskóla greindar eftir pví hvort viðkomandi hafi lokið prófi frá bæði íslenskum og erlendum háskóla eða einungis frá erlendum háskóla. Alls höfðu 38\% svarenda lokið prófi frá einum háskóla, 8\% frá tveimur háskólum en innan við hálft prósent frá premur eða fleiri háskólum. Tekið er tillit til pess við úrvinnslu gagnanna.

\section{Úrvinnsla gagna}

Eftirfarandi greining er prípætt. Í fyrsta lagi er mikilvægi einstakra landshluta sem vettvangs fyrir brautskráða nemendur hvers háskóla um sig metið með pví að kortleggja búsetu peirra sem paðan hafa lokið námi. Pannig er t.d. hægt að bera saman hversu hátt hlutfall brautskráđra nemenda frá Hí 
og HA býr á höfuðborgarsvæðinu eða hversu hátt hlutfall peirra sem lokið hafa námi frá LHÍ annars vegar og LBHÍ hins vegar býr á strjálbýlli svæðum landsins. Búseta peirra sem brautskráđir eru frá erlendum háskólum er skoðuð sérstaklega en par sem gögnin eru byggð á úrtaki íbúa á Íslandi veita pau ekki upplýsingar um brautskráđa nemendur sem búsettir eru erlendis.

Í öðru lagi er mikilvægi einstakra háskóla metið út frá sjónarhóli hvers svæðis um sig með pví að kortleggja hvaðan háskólamenntaðir íbúar hafa útskrifast. Pannig er t.d. hægt að bera saman hversu hátt hlutfall háskólamenntaðs fólks á höfuðborgarsvæðinu hefur lokið prófi frá HÍ og HR eða hversu hátt hlutfall peirra sem búa á strjálbýlli svæðum landsins hefur lokið prófi frá HA annars vegar og LBHÍ hins vegar. Í peirri greiningu er fjölda peirra sem lokið hafa prófi frá fleiri en einum háskóla deilt jafnt milli viðkomandi háskóla.

Í priðja lagi er hlutdeild hvers háskóla í menntunarstigi landsvæða áætlað út frá manntalinu 2011 og hlutfalli háskólanna af heildarfjölda háskólamenntaðra á hverju landsvæði. Dannig er t.d. hægt að áætla hlutdeild HÍ, HR og annarra háskóla í peim 39\% íbúa höfuðborgarsvæðisins á aldrinum 25-64 ára sem lokið hafa háskólaprófi samkvæmt manntali Hagstofu Íslands (2017b).

\section{Niðurstöður}

\section{Búseta eftir háskólum}

Tafla 2 sýnir búsetu 25-64 ára svarenda sem lokið hafa prófi frá einstökum háskólum innan og utan Reykjavíkur. Par má sjá að 79\% svarenda frá háskólunum í Reykjavík en aðeins 44\% svarenda frá landsbyggðaháskólunum eru búsett á höfuðborgarsvæðinu (79-44£4\%). Nemendur frá HB eru marktækt ólíklegri til að búa á höfuðborgarsvæðinu en nemendur frá Reykjavíkurháskólunum (63-

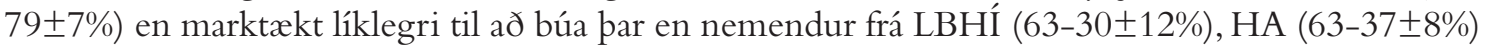

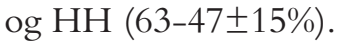

Tafla 2. Búseta brautskráðra nemenda frá einstökum háskólum eftir svæðum

\begin{tabular}{|c|c|c|c|c|c|c|}
\hline & $\begin{array}{c}\text { Höfudb. } \\
\text { svaedi }\end{array}$ & $\begin{array}{c}S V- \\
\text { péttbýli }\end{array}$ & $\begin{array}{l}\text { Suдиr- } \\
\text { svaði }\end{array}$ & $\begin{array}{l}\text { Norður- } \\
\text { svaedi }\end{array}$ & Akureyri & Fjöldi \\
\hline Reykjavík & $79 \pm 1 \%$ & $8 \pm 1 \%$ & $4 \pm 1 \%$ & $5 \pm 1 \%$ & $3 \pm 1 \%$ & 4.074 \\
\hline Háskóli Íslands & $79 \pm 2 \%$ & $8 \pm 1 \%$ & $4 \pm 1 \%$ & $6 \pm 1 \%$ & $3 \pm 1 \%$ & 3.431 \\
\hline Háskólinn í Reykjavík & $82 \pm 3 \%$ & $9 \pm 2 \%$ & $3 \pm 1 \%$ & $4 \pm 2 \%$ & $3 \pm 2 \%$ & 677 \\
\hline Listaháskólinn & $81 \pm 8 \%$ & $7 \pm 4 \%$ & $3 \pm 3 \%$ & $6 \pm 5 \%$ & $3 \pm 4 \%$ & 116 \\
\hline Utan Reykjavíkur & $44 \pm 3 \%$ & $10 \pm 2 \%$ & $9 \pm 2 \%$ & $19 \pm 3 \%$ & $18 \pm 3 \%$ & 756 \\
\hline Háskólinn á Akureyri & $37 \pm 4 \%$ & $8 \pm 2 \%$ & $4 \pm 2 \%$ & $22 \pm 4 \%$ & $30 \pm 4 \%$ & 459 \\
\hline Háskólinn á Bifröst & $63 \pm 7 \%$ & $13 \pm 5 \%$ & $12 \pm 5 \%$ & $9 \pm 5 \%$ & $3 \pm 3 \%$ & 181 \\
\hline Háskólinn á Hólum & $47 \pm 13 \%$ & $16 \pm 10 \%$ & $10 \pm 8 \%$ & $25 \pm 12 \%$ & $2 \pm 5 \%$ & 53 \\
\hline Landbúnaðarháskóli & $30 \pm 9 \%$ & $10 \pm 6 \%$ & $22 \pm 9 \%$ & $36 \pm 10 \%$ & $1 \pm 1 \%$ & 87 \\
\hline Erlendir háskólar & $82 \pm 2 \%$ & $6 \pm 1 \%$ & $4 \pm 1 \%$ & $4 \pm 1 \%$ & $4 \pm 1 \%$ & 1.435 \\
\hline Íslenskur og erlendur & $86 \pm 3 \%$ & $5 \pm 2 \%$ & $3 \pm 1 \%$ & $3 \pm 1 \%$ & $4 \pm 2 \%$ & 686 \\
\hline Erlendur eingöngu & $79 \pm 3 \%$ & $7 \pm 2 \%$ & $5 \pm 2 \%$ & $5 \pm 2 \%$ & $4 \pm 2 \%$ & 749 \\
\hline Samtals skv. könnun & $76 \pm 2 \%$ & $8 \pm 3 \%$ & $5 \pm 3 \%$ & $7 \pm 3 \%$ & $5 \pm 3 \%$ & 5.380 \\
\hline $\begin{array}{l}\text { Háskólamenntaðir } \\
\text { 26-64 ára skv. manntali }\end{array}$ & $76 \%$ & $7 \%$ & $5 \%$ & $5 \%$ & $7 \%$ & 53.908 \\
\hline $\begin{array}{l}\text { Íbúar 25-64 ára } \\
\text { skv. manntali }\end{array}$ & $65 \%$ & $11 \%$ & $8 \%$ & $5 \%$ & $11 \%$ & 163.048 \\
\hline
\end{tabular}


Deir sem brautskráđir voru frá erlendum háskóla eingöngu voru jafn líklegir til að búa á höfuðborgarsvæðinu og brautskráðir nemendur HÍ, en peir sem lokið höfðu námi við íslenskan og erlendan háskóla voru líklegastir allra til að búa á höfuðborgarsvæðinu $(86 \pm 3 \%)$. Nemendur frá erlendum háskólum eingöngu voru álíka líklegir og nemendur frá Reykjavíkurháskólunum til að búa utan höfuðborgarsvæðisins, en peir voru hins vegar ólíklegri til pess en nemendur frá lands-

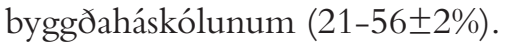

Á landsvísu voru 8\% ( $\pm 3 \%)$ háskólamenntaðra svarenda búsettir í SV-péttbýli og er pað hlutfall ekki marktækt ólíkt eftir háskólum. Á suðursvæðinu bjó hins vegar marktækt lægra hlutfall brautskráðra

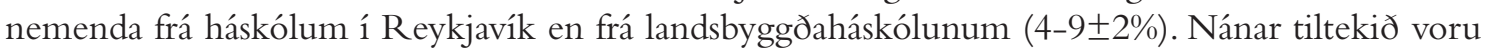
nemendur frá Reykjavíkurháskólunum marktækt ólíklegri til að búa á suðursvæðinu en nemendur

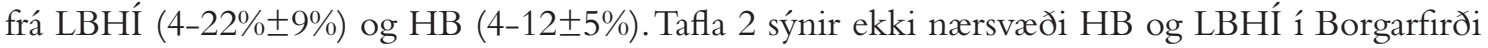
sérstaklega innan suðursvæðisins. Nánari greining leiðir hins vegar í ljós að 5\% ( $\pm 3 \%)$ brautskráđra nemenda HB og 10\% ( $\pm 6 \%)$ brautskráđra nemenda LBHÍ búa í Borgarfirði.

Á norðursvæðinu bjuggu 5\% peirra svarenda sem lokið höfðu háskólaprófi í Reykjavík en 19\% peirra sem útskrifuðust frá landsbyggðaháskólunum (5-19\%土3\%). Hæst var hlutfallið meðal brautskráđra nemenda LBHÍ, en 36\% peirra bjuggu á norðursvæðinu samanborið við t.d. $22 \%$ braut-

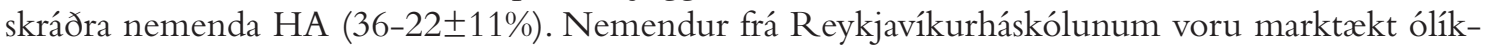


norðursvæðisins sýnir tafla 2 hvorki nærsvæði HH í Skagafirði né nærsvæði HA á Norðurlandi eystra utan Akureyrar. Nánari greining leiðir hins vegar í ljós að 10\% ( $\pm 8 \%)$ brautskráđra nemenda HH búa í Skagafirði og 10\% ( $\pm 5 \%)$ brautskráðra nemenda HA á Norðurlandi eystra utan Akureyrar.

Á Akureyri bjuggu 3\% peirra sem lokið höfðu háskólaprófi í Reykjavík en 18\% peirra sem luku

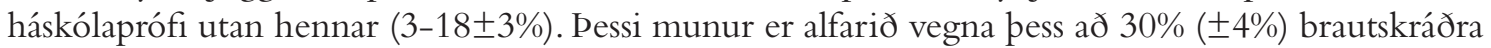
nemenda frá HA er búsettur á Akureyri, sem er marktækt hærra en meðal nemenda Reykjavíkur-

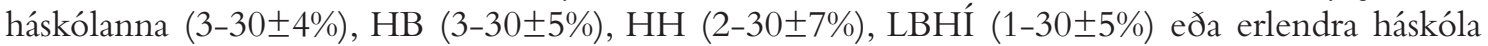
(4-36 $\pm 5 \%)$. Brautskráđir nemendur frá LBHÍ voru jafnframt marktækt ólíklegri til að búa á Akur-

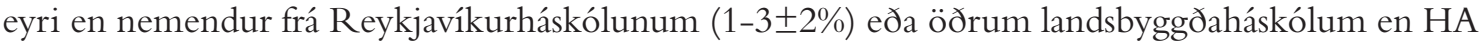
$(1-5 \pm 3 \%)$.

\section{Háskólamenntun eftir búsetu}

Tafla 3 sýnir hlutfall háskólamenntaðra íbúa einstakra svæða sem lokið hafa prófi frá mismunandi háskólum. Eins og sjá má lækkar hlutfall háskólamenntaðra sem lokið hafa prófi frá háskólum í Reykjavík eftir pví sem fjær dregur borginni. Hlutfallið er hæst $80 \%$ ( $\pm 1 \%)$ á höfuðborgarsvæðinu en ekki marktækt lægra í SV-péttbýli (80-77£4\%). Hlutfallið í SV-péttbýli er hins vegar marktækt


$( \pm 5 \%)$ á Akureyri sem er marktækt lægra en á öllum öðrum svæðum. 
Tafla 3. Háskólamenntaðir íbúar frá einstökum háskólum eftir svæðum.

\begin{tabular}{|c|c|c|c|c|c|c|}
\hline & $\begin{array}{c}\text { Höfuðb. } \\
\text { svæði }\end{array}$ & $\begin{array}{c}\text { SV- } \\
\text { péttbýli }\end{array}$ & $\begin{array}{l}\text { Suður- } \\
\text { svæði }\end{array}$ & $\begin{array}{c}\text { Norður- } \\
\text { svæði }\end{array}$ & $\begin{array}{c}\text { Akur- } \\
\text { eyri }\end{array}$ & Landið \\
\hline Háskólar í Reykjavík & $80 \pm 1 \%$ & $77 \pm 4 \%$ & $67 \pm 6 \%$ & $61 \pm 4 \%$ & $53 \pm 5 \%$ & $77 \pm 1 \%$ \\
\hline Háskóli Íslands & $67 \pm 1 \%$ & $64 \pm 5 \%$ & $60 \pm 6 \%$ & $53 \pm 4 \%$ & $46 \pm 5 \%$ & $65 \pm 1 \%$ \\
\hline Háskólinn í Reykjavík & $14 \pm 1 \%$ & $14 \pm 3 \%$ & $7 \pm 3 \%$ & $7 \pm 2 \%$ & $8 \pm 3 \%$ & $13 \pm 1 \%$ \\
\hline Listaháskólinn & $2 \pm 1 \%$ & $2 \pm 1 \%$ & $2 \pm 1 \%$ & $2 \pm 1 \%$ & $2 \pm 2 \%$ & $2 \pm 1 \%$ \\
\hline Utan Reykjavíkur & $7 \pm 1 \%$ & $15 \pm 3 \%$ & $24 \pm 5 \%$ & $35 \pm 4 \%$ & $48 \pm 5 \%$ & $13 \pm 1 \%$ \\
\hline Háskólinn á Akureyri & $4 \pm 1 \%$ & $7 \pm 2 \%$ & $7 \pm 3 \%$ & $23 \pm 4 \%$ & $45 \pm 5 \%$ & $7 \pm 1 \%$ \\
\hline Háskólinn á Bifröst & $3 \pm 1 \%$ & $5 \pm 2 \%$ & $9 \pm 3 \%$ & $4 \pm 2 \%$ & $2 \pm 2 \%$ & $3 \pm 1 \%$ \\
\hline Háskólinn á Hólum & $1 \pm 0,2 \%$ & $2 \pm 1 \%$ & $2 \pm 2 \%$ & $3 \pm 2 \%$ & $<1 \pm 1 \%$ & $1 \pm 1 \%$ \\
\hline Landbúnaðarháskólinn & $1 \pm 0,2 \%$ & $2 \pm 1 \%$ & $7 \pm 3 \%$ & $7 \pm 3 \%$ & $<1 \pm 1 \%$ & $1 \pm 1 \%$ \\
\hline Erlendir háskólar & $30 \pm 1 \%$ & $20 \pm 4 \%$ & $22 \pm 5 \%$ & $17 \pm 3 \%$ & $20 \pm 4 \%$ & $27 \pm 1 \%$ \\
\hline Íslenskur og erlendur & $15 \pm 1 \%$ & $8 \pm 2 \%$ & $8 \pm 3 \%$ & $6 \pm 2 \%$ & $10 \pm 3 \%$ & $13 \pm 1 \%$ \\
\hline Erlendur eingöngu & $15 \pm 1 \%$ & $13 \pm 3 \%$ & $14 \pm 4 \%$ & $11 \pm 3 \%$ & $10 \pm 3 \%$ & $14 \pm 1 \%$ \\
\hline ALLS & $76 \pm 2 \%$ & $8 \pm 3 \%$ & $5 \pm 3 \%$ & $7 \pm 3 \%$ & $5 \pm 3 \%$ & $101 \%$ \\
\hline Fjöldi svarenda & 3.807 & 428 & 293 & 488 & 371 & 5.377 \\
\hline
\end{tabular}

Með svipuðum hætti hækkar hlutfall háskólamanna með próf frá háskólum utan Reykjavíkur

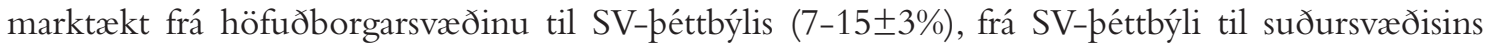

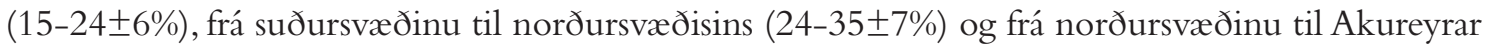

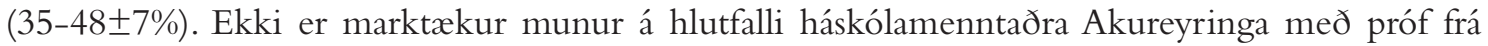

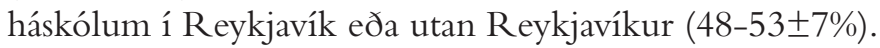

pegar litið er til einstakra háskóla kemur í ljós að brautskráđir nemendur frá HÍ eru meirihluti háskólafólks á öllum svæðum nema á Akureyri. Ekki er marktækur munur á hlutfalli háskólafólks með próf frá HÍ á höfuðborgarsvæðinu og SV-péttbýli (67-64_4\%), en hlutfall nemenda frá Hí er

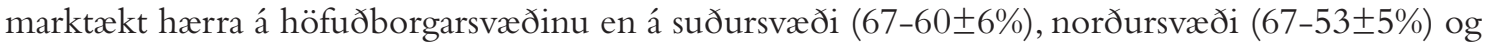
Akureyri (67-46士5\%).

HR á næstmesta hlutdeild í háskólamenntuðum íbúum á höfuðborgarsvæðinu og SV-péttbýli par sem 14\% háskólamenntaðra íbúa hafa útskrifast frá háskólanum. Utan SV-péttbýlis eru á hinn bóginn aðeins 7-8\% háskólamenntaðra íbúa frá HR. Munurinn á hlutdeild HR á höfuðborgarsvæðinu og SV-péttbýli annars vegar og öðrum landsbyggðum hins vegar er tölfræðilega marktækur $(14-7 \pm 2 \%)$. Á höfuðborgarsvæðinu er hlutdeild HA 4\% ( $\pm 1 \%)$ og hlutdeild HB 3\% ( $\pm 1 \%)$, en 1 SV-péttbýli er hlutdeild HA 7\% ( $\pm 2 \%)$ og HB 5\% ( $\pm 2 \%)$. Hlutdeild einstakra annarra háskóla í Reykjavík og SV-péttbýli er 2\% eða minna.

Á suðursvæðinu mælist HB með næstmesta hlutdeild háskólamenntaðra íbúa (9\% 3\%) en ekki er

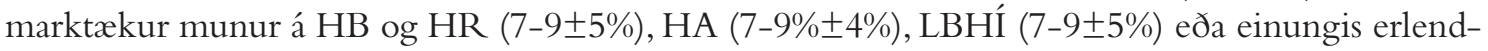

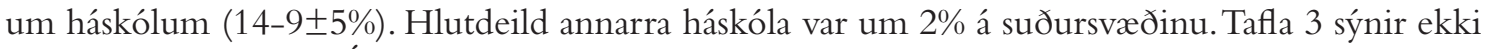
nærsvæði HB og LBHÍ í Borgarfirði sérstaklega innan suðursvæðisins en nánari greining sýnir að

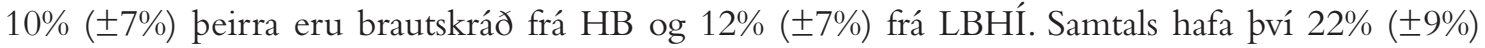
háskólamenntaðra Borgfirðinga lokið háskólaprófi frá pessum tveimur háskólum í Borgarfirði.

HA á næstmesta hlutdeild í háskólamenntuðum íbúum á norðursvæðinu utan Akureyrar, með um

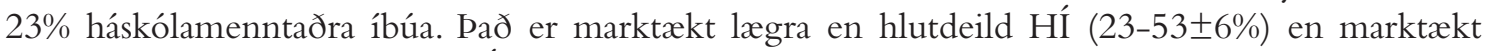

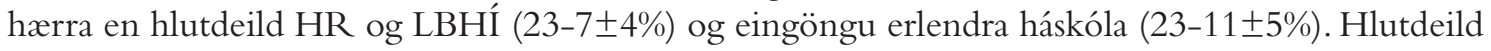


annarra háskóla í háskólamenntuðum íbúum norðursvæðisins var á bilinu 2-4\%. Innan norðursvæðisins sýnir tafla 3 hvorki nærsvæði HH í Skagafirði né nærsvæði HA á Norðurlandi eystra utan Akureyrar. Nánari greining leiðir hins vegar í ljós að 10\% ( $\pm 8 \%)$ háskólamenntaðra Skagfirðinga hafa lokið prófi frá HH en 33\% ( $\pm 10 \%)$ háskólamenntaðra íbúa Norðurlands eystra hafa lokið prófi frá HA.

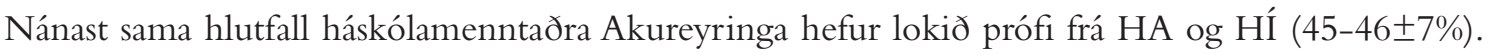
Ekki er heldur marktækur munur á hlutfalli peirra sem hafa lokið prófi frá HR og einungis erlend-

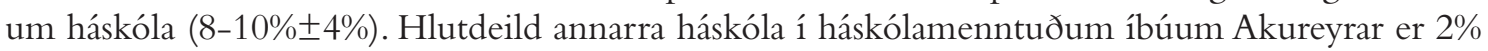
eða lægri.

\section{Áhrif háskóla á menntunarstig og menntabil}

Tafla 4 sýnir áætluð áhrif einstakra háskóla á menntunarstig og menntabil milli landshluta. Áhrifin eru reiknuð út frá samsetningu úrtaks háskólamenntaðra á hverju svæði samkvæmt niðurstöðum manntalsins og skiptingu peirra milli háskóla samkvæmt könnun Gallup. Pannig telst einstaklingur sem aðeins hefur lokið prófi frá einum háskóla að fullu til pess háskóla, sá sem hefur lokið prófi frá tveimur háskólum telst að hálfu til hvors háskóla og pannig koll af kolli.

Tafla 4. Áhrif einstakra háskóla á menntabil háskólamenntaðra eftir svæðum.

\begin{tabular}{lcccccc}
\hline & $\begin{array}{c}\text { Höfuðb. } \\
\text { svæði }\end{array}$ & $\begin{array}{c}\text { SV- } \\
\text {-pétt- } \\
\text { býli }\end{array}$ & $\begin{array}{c}\text { Suður- } \\
\text { svæði }\end{array}$ & $\begin{array}{c}\text { Norður- } \\
\text { svæði }\end{array}$ & Akureyri & Landið \\
\hline Háskólar í Reykjavík & $\mathbf{2 8 \%}$ & $\mathbf{1 4 \%}$ & $\mathbf{1 3 \%}$ & $\mathbf{1 2 \%}$ & $\mathbf{1 3 \%}$ & $\mathbf{2 2 \%}$ \\
Háskóli Íslands & $23 \%$ & $11 \%$ & $11 \%$ & $11 \%$ & $11 \%$ & $18 \%$ \\
Háskólinn í Reykjavík & $5 \%$ & $3 \%$ & $1 \%$ & $1 \%$ & $2 \%$ & $3 \%$ \\
Listaháskólinn & $1 \%$ & $0 \%$ & $0 \%$ & $0 \%$ & $0 \%$ & $1 \%$ \\
Utan Reykjavíkur & $\mathbf{2 \%}$ & $\mathbf{2 \%}$ & $\mathbf{4 \%}$ & $\mathbf{7 \%}$ & $\mathbf{1 3} \%$ & $\mathbf{4} \%$ \\
Háskólinn á Akureyri & $1 \%$ & $1 \%$ & $1 \%$ & $4 \%$ & $12 \%$ & $2 \%$ \\
Háskólinn á Bifröst & $1 \%$ & $1 \%$ & $2 \%$ & $1 \%$ & $1 \%$ & $1 \%$ \\
Háskólinn á Hólum & $0 \%$ & $0 \%$ & $0 \%$ & $1 \%$ & $0 \%$ & $0 \%$ \\
Landbúnaðarháskólinn & $0 \%$ & $0 \%$ & $1 \%$ & $1 \%$ & $0 \%$ & $0 \%$ \\
Erlendir háskólar & $\mathbf{9 \%}$ & $\mathbf{3} \%$ & $\mathbf{4} \%$ & $\mathbf{3} \%$ & $\mathbf{5 \%}$ & $\mathbf{7 \%}$ \\
Samtals & $\mathbf{3 9 \%}$ & $\mathbf{2 0} \%$ & $\mathbf{2 1 \%}$ & $\mathbf{2 2 \%}$ & $\mathbf{3 1 \%}$ & $\mathbf{3 3} \%$ \\
\hline
\end{tabular}

Samkvæmt manntali 2011 höfðu 39\% íbúa höfuðborgarsvæðisins á aldrinum 25-64 ára lokið háskólaprófi. Par af teljast áhrif allra priggja háskólanna í Reykjavík samtals $28 \%$ af mannfjöldanum. Áhrif landsbyggðaháskólanna fjögurra eru aðeins $2 \%$ en áhrif erlendra háskóla teljast vera $9 \%$ mannfjöldans. Á Akureyri hafði 31\% íbúa á pessum aldri lokið háskólaprófi en 20-22\% í öðrum landshlutum. Utan höfuðborgarsvæðisins eru áhrif háskólanna í Reykjavík 12-14\% en áhrif landsbyggðaháskólanna eru 2-13\% af mannfjölda.

Áhrif einstakra háskóla í Reykjavík og erlendra háskóla á menntunarstig eru almennt u.p.b. tvöfalt meiri á höfuðborgarsvæðinu en utan pess. Pannig teljast áhrif HÍ samsvara 23\% mannfjöldans á höfuðborgarsvæðinu en 11\% mannfjöldans í SV-péttbýli, á suðursvæði, norðursvæði og Akureyri. Samanlögð áhrif HR og LHÍ samsvara með svipuðum hætti 6\% á höfuðborgarsvæðinu en 1-3\% í öðrum landshlutum. Loks samsvara áhrif erlendra háskóla 9\% mannfjöldans á höfuðborgarsvæðinu en 3-5\% á öðrum landsvæðum. 
Samkvæmt pessum niðurstöðum hefur HA dregið verulega úr menntabili í háskólamenntun milli Akureyrar og höfuðborgarsvæðisins. Háskólarnir í Reykjavík hafa svipuð áhrif á menntunarstig á Akureyri og annars staðar utan höfuðborgarsvæðisins en aðrir landsbyggðaháskólar hafa ívið minni áhrif. Dví virðast brautskráđir nemendur frá HA sem búsettir eru á Akureyri vera hrein viðbót við pann fjölda sem háskólarnir í Reykjavík skila inn á svæði utan höfuðborgarsvæðisins.

Jafnframt eru vísbendingar um að HA og aðrir landsbyggðaháskólar hafi hækkað menntunarstig nokkuð á norðursvæðinu og í minni mæli á suðursvæðinu. Landsbyggðaháskólarnir hafa samanlagt útskrifað 7\% íbúa norðursvæðisins á pessu aldursbili, 4\% íbúa suðursvæðisins og 2\% íbúa SV-péttbýlis. HR hefur hins vegar meiri áhrif en landsbyggðaháskólarnir á menntunarstig á höfuðborgarsvæðinu og nærliggjandi byggðarlögum.

Dótt verulegur hluti brautskráđra nemenda frá HB, HH og LBHÍ búi utan höfuðborgarsvæðisins eru pessir háskólar of litlir til að hafa veruleg áhrif á menntunarstig stærri svæða. Pannig má áætla að 2\% íbúa suðursvæðisins og 1\% íbúa annarra svæða hafi lokið prófi frá HB. Um 1\% íbúa norðursvæðisins hefur lokið prófi frá $\mathrm{HH}$ en innan við hálft prósent annarra svæða. Loks hefur innan við hálft prósent íbúa SV-péttbýlis og Akureyrar lokið prófi frá LBHÍ en um 1\% íbúa annarra, strjálbýlli svæða.

\section{Umræða}

Víða um heim hafa sjálfstæðar háskólastofnanir verið settar á fót til að draga úr mun á háskólamenntun og auka samkeppnishæfni landsvæða (Anderssen o.fl., 2004, 2009; Arbo og Eskelinen, 2003; Frenette, 2009; Lehmann o.fl., 2009; Nilsson, 2006; Tomaney og Wray, 2011). Pótt heildstæð stefnumótun á pessu sviði sé ekki fyrir hendi hér á landi voru slík rök sett fram til stuðnings stofnun HÍ undir lok 19. aldar (Jón Dorkelsson, 1891) og stofnun HA eftir miðja 20. öldina (Alpingi, 1964). Jafnframt eru jákvæð áhrif á efnahagslíf og menntunarstig iðulega nefnd til stuðnings sjálfstæðum háskólum í dreifoum byggðum (Ingi Rúnar Eðvarðsson, 2014; Kolfinna Jóhannesdóttir og Vífill Karlsson, 2010;Vífill Karlsson og Magnús B. Jónsson, 2013).

Enginn vafi er á pví að Háskóli Íslands hefur eflt Reykjavík sem pungamiðju íslensks menntalífs og vísinda eins og stefnt var að í sjálfstæðisbaráttu 19. aldar (Jón Dorkelsson, 1891). HÍ hefur pjónað pörfum íslensks atvinnulífs, stjórnsýslu og menningar (Gunnar Karlsson, 2011) og stúdentar háskólans hafa án efa auðgað mannlíf og verslun í Reykjavík. Pá má færa rök fyrir pví að staða Hí á lista Times Higher Education World University Rankings yfir 250 bestu háskóla í heimi (Háskóli Íslands 2016a) uppfylli að nokkru draum Jóns Porkelssonar (1891, bls. 31) um að „landið sjálft yxi í augum hinna mentuðu pjóða“. Ótti við að fjölgun íslenskra háskóla myndi leiða til hnignunar HÍ virðist jafnframt hafa reynst ástæðulaus pótt bág fjárhagsstaða háskólans sé enn iðulega nefnd sem rök fyrir pví að leggja aðra háskóla undir hann (sjá t.d. Magnús Guðmundsson, 2011).

Dótt Hí hafi pannig eflaust dregið mjög úr manntjóni Íslands vegna Kaupmannahafnarferða háskólastúdenta (Jón Porkelsson, 1891) virðist ljóst að aðeins um helmingur nemenda háskólans frá öðrum landshlutum eigi afturkvæmt í heimabyggð eftir brautskráningu (Póroddur Bjarnason og Ingi Rúnar Eðvarðsson, 2017). Niðurstöður pessarar rannsóknar benda til pess að hlutfall brautskráđra nemenda frá HÍ sé tvöfalt hærra á höfuðborgarsvæðinu en utan pess. Pannig hafa 23\% íbúa höfuðborgarsvæðisins en 11\% íbúa annarra svæða á aldrinum 25-64 ára lokið prófi frá HÍ. Svipaðar niðurstöður hafa komið fram 1 öðrum löndum par sem minnihluti peirra sem fara til háskólanáms utan heimabyggðar snýr aftur heim að námi loknu (Blackwell o.fl., 2002; Corcoran o.fl., 2010; Haapanen og Tervo, 2012; Hoare og Corver, 2010).

Háskólinn á Akureyri var stofnsettur árið 1987, pegar viðskipta- og iðnaðarveldi Kaupfélags Eyfirðinga og Sambands íslenskra samvinnufélaga riðaði til falls. Á næstu árum lagðist verksmiðjurekstur að mestu af á Akureyri en margvísleg pjónustustarfsemi óx að sama skapi. Íbúum hefur fjölgað jafnt og pétt og borgarsamfélag hefur skapast sem styður við byggð á Norður- og Austurlandi. Hlut- 
fall háskólamenntaðra á Akureyri er miðja vegu milli höfuðborgarsvæðisins og annarra landshluta og virðist pað alfarið vera fyrir áhrif HA. Dar er bæði um að ræða Akureyringa sem hafa sótt sér menntun í heimabyggð við HA og fólk frá öðrum landshlutum sem ílengst hefur á Akureyri eftir nám við HA (Dóroddur Bjarnason og Ingi Rúnar Eðvarðsson, 2017).

Orsakasambandið milli fjölgunar háskólamenntaðra íbúa og breytinga í atvinnulífi á Akureyri er pó margslungið og pví verður ekki fullsvarað hvort fleiri brautskráðir frá öđrum háskólum væru búsettir á Akureyri ef HA hefði ekki komið til. Akureyringar eru pó ekki líklegri en íbúar annarra landsbyggða til að snúa heim að loknu háskólaprófi við HÍ í Reykjavík og höfuðborgarbúar sem útskrifast frá HÍ eru ekki líklegri til að flytja til Akureyrar en annarra svæða utan höfuðborgarsvæðisins (Póroddur Bjarnason og Ingi Rúnar Eðvarđsson, 2017; Dóroddur Bjarnason o.fl., 2016).Á hinn bóginn er hlutfall Akureyringa sem verða um kyrrt eftir útskrift frá HA næstum jafn hátt og hlutfall háskólanema af höfuðborgarsvæðinu sem verða um kyrrt eftir útskrift frá HÍ, og umtalsverður hluti staðarnema frá öðrum svæðum ílengist á Akureyri eftir útskrift frá HA. Dað má pví teljast fremur ólíklegt að háskólar í Reykjavík hefðu fyllt í menntaskarðið ef HA hefði ekki verið stofnaður árið 1987.

Niðurstöður pessarar rannsóknar sýna nokkuð skýrt landfræðilegt mynstur í búsetu brautskráðra háskólanema. Háskóli Íslands á mesta hlutdeild í háskólamenntuðum íbúum á öllum landsvæðum, að Akureyri undanskilinni par sem nánast sama hlutfall hefur lokið prófi frá HA og frá HÍ. Háskólinn í Reykjavík á næstmesta hlutdeild í háskólamenntuðum íbúum á höfuðborgarsvæðinu og í SV-péttbýlinu í nágrenni pess, en HA á næstmesta hlutdeild í brautskráđum nemendum á norðursvæðinu frá Vestfjörðum norður um til Austurlands. Á suðursvæði landsins frá Snæfellsnesi að Hornafirði, að helsta áhrifasvæði Reykjavíkur undanskildu, eiga Háskólinn í Reykjavík, Háskólinn á Bifröst, Landbúnaðarháskóli Íslands og Háskólinn á Akureyri svipaða hlutdeild í háskólamenntuðum íbúum.

Á síðustu árum hefur fjarnám farið ört vaxandi við íslenska háskóla og munurinn á staðarnemum og fjarnemum jafnframt orðið óljósari (Anna Guðrún Edvardsdóttir, 2016; Ingi Rúnar Eðvarðsson, 2014; Rennie o.fl., 2011; Póroddur Bjarnason og Brynhildur Dórarinsdóttir, 2018; Dóroddur Barnason og Ingi Rúnar Eðvarðsson, 2017; Póroddur Bjarnason o.fl., 2016; Puríður J. Jóhannsdóttir, 2010). Fjarnemar eru um helmingur nemenda við Háskólann á Akureyri, um tveir af hverjum premur nemendum við Háskólann á Hólum og prír af hverjum fjórum við Háskólann á Bifröst (Bóroddur Bjarnason o.fl., 2016). Hlutfall fjarnema er aðeins um 4\% við Háskólann í Reykjavík, og engir fjarnemar eru skráðir við Listaháskóla Íslands. Skráningarkerfi Háskóla Íslands gerir ekki greinarmun á fjarnemum og staðarnemum en um $8 \%$ peirra taka a.m.k. eitt námskeið í fjarnámi á námsferli sínum (Dóroddur Bjarnason o.fl., 2016).

Staðsetning háskóla virðist skipta miklu máli fyrir framtíðarbúsetu staðarnema en litlu máli fyrir framtíðarbúsetu fjarnema. Pannig eru fjarnemar sem stunda nám í heimabyggð á dreifbýlum svæðum álíka líklegir til að búa áfram í heimabyggð og heimafólk við háskólana í Reykjavík og á Akureyri (Dóroddur Bjarnason o.fl., 2016). Staðsetning háskólans virðist ekki skipta höfuðmáli hvað áhrif fjarnáms varðar, en fjarnemar við menntavísindasvið Háskóla Íslands eru álíka líklegir og fjarnemar við kennaradeild Háskólans á Akureyri til að búa áfram í dreifðari byggðum (Dóroddur Bjarnason og Brynhildur Pórarinsdóttir, 2018). Tíminn mun leiða í ljós hvaða áhrif aukið vægi fjarnáms við íslenska og erlenda háskóla á eftir að hafa á menntunarstig og menntabil milli landshluta.

Sýnt hefur verið fram á veruleg efnahagsleg áhrif af umsvifum minni háskóla á efnahagslíf og rekstur sveitarfélaga utan höfuðborgarsvæðisins (Ingi Rúnar Eðvarðsson, 2014; Kolfinna Jóhannesdóttir og Vífill Karlsson, 2010;Vífill Karlsson og Magnús B. Jónsson, 2013). Erfiðara er að greina nákvæmlega áhrif háskóla í dreifbýli á menntunarstig nærsamfélaganna. Eðli málsins samkvæmt er lítill hluti nemendahópsins úr dreifbýlu nærsamfélagi pessara háskóla, en verulegur hluti peirra verður pó um kyrrt eftir brautskráningu ('óroddur Bjarnason o.fl., 2016). Niðurstöður pessarar rannsóknar benda til pess að 5-10\% brautskráđra nemenda frá Háskólanum á Bifröst, Landbúnaðarháskólanum og Háskólanum á Hólum búi á nærsvæðum háskólanna. Á hinn bóginn hefur um einn af hverjum 
tíu háskólamenntuðum Skagfirðingum lokið prófi frá Háskólanum á Hólum og nærri fjórðungur háskólamenntaðra Borgfirðinga hefur lokið prófi frá Háskólanum á Bifröst eða Landbúnaðarháskólanum. Með svipuðum hætti býr um einn af hverjum tíu brautskráðum nemendum HA á Norðurlandi eystra en einn af hverjum premur háskólamenntuðum íbúum Norðurlands eystra hefur lokið prófi frá HA.

Hvað samkeppnishæfni landsvæða varðar er nauðsynlegt að huga að ýmsum páttum sem pessi rannsókn nær ekki til. Dótt háskólarnir starfi undir sameiginlegu gæðakerfi og gæði háskólagráða séu metin með reglubundnum hætti af albjóðlegum matsnefndum (Rannís, 2017a, 2017b) væri full ástæða til að meta sérstaklega hvernig brautskráđum nemendum einstakra háskóla farnast að námi loknu og að hvaða marki fólk vinnur störf par sem háskólamenntun pess nýtist (sjá t.d. Jason Má Bergsteinsson, Inga Rúnar Eðvarðsson og Guðmund Kristján Óskarsson, 2017). Í pví sambandi er vitaskuld mikilvægt að skoða hvort landsbyggðaháskólarnir búi nemendur betur undir störf utan höfuðborgarsvæðisins en peir háskólar sem staðsettir eru í Reykjavík og miða námsframboð sitt e.t.v. í ríkari mæli við vinnumarkað borgarinnar eða annarra landa.

Loks er ástæða til að huga sérstaklega að áhrifum pess að námsframboð landsbyggðaháskólanna er mun prengra en háskólanna í Reykjavík. Pannig er mikilvægt fyrir samkeppnishæfni Skagafjarðar að par starfi háskólafólk á fleiri sviðum en t.d. fiskeldi, hestafræði og ferðamálafræði sem kennd eru við Háskólann á Hólum. Með sama hætti má velta fyrir sér áhrifum pess að helmingur háskólamenntaðra Akureyringa hefur lokið prófi frá HA sem býður aðeins upp á nám í heilbrigðisvísindum, félags- og menntavísindum og auðlindafræði. Pannig mætti spyrja hvaða áhrif pað hefði á samfélag og efnahagslíf á Norðurlandi ef HA byði einnig upp á háskólanám í t.d. verkfræði og tæknigreinum, hönnun eða listum.

Samkvæmt lögum hafa íslenskir háskólar m.a. pað hlutverk að stuðla að miðlun pekkingar og færni til nemenda og samfélagsins alls og styrkja pannig innviði íslensks samfélags og stöðu pess 1 alpjóðlegu tilliti (Alpingi, 2006). Í lögunum er litið á íslenskt samfélag sem órofa heild og ekki gert ráð fyrir pví að háskólar hafi sérstökum skyldum að gegna hvað varðar miðlun pekkingar og færni til allra landshluta eða styrkingu innviða einstakra samfélaga innan ríkisheildarinnar. Í stefnum háskólanna priggja í Reykjavík er einnig undantekningarlaust talað um íslenskt samfélag í eintölu og hvergi vikið að pví sem markmiði að draga úr menntabili milli landshluta (Háskóli Íslands, 2016b; Háskólinn í Reykjavík, 2017; Listaháskóli Íslands, 2017), pótt í stefnu HÍ sé vikið að eflingu rannsóknasetra á „landsbyggðinni““ og sampættingu peirra við fræðasvið og deildir háskólans.

Svæðisbundin áhrif á menntunarstig í landsbyggðunum hafa verið ein helstu rökin fyrir sjálfstæðum háskólum utan Reykjavíkur (sjá t.d. Alpingi, 2011; Braga Guðmundsson, 2012; Eyping, 2011; Ingibjörgu Einarsdóttur, 2010; Jón Bjarnason, 2013; Kolfinnu Jóhannesdóttur og Vífil Karlsson, 2010; Magnús B. Jónsson, 2013; Sindra Sigurgeirsson, 2013). Í pví ljósi er athyglisvert að enginn landsbyggðaháskólanna hefur pá yfirlýstu stefnu að minnka menntabilið milli höfuðborgarsvæðisins og annarra landshluta (Háskólinn á Akureyri, 2012; Háskólinn á Bifröst, 2012; Háskólinn á Hólum, 2016; Landbúnaðarháskólinn, 2009), pótt Háskólinn á Bifröst leggi áherslu á að vinna með og pjóna nærsamfélagi sínu og ,,vegna staðsetningar sinnar gegn[i] Háskólinn á Akureyri lykilhlutverki í eflingu háskólamenntunar, rannsókna, próunar og nýsköpunar á landsbyggðđinni og nemendur úr öllum byggðum landsins sæk[i] í pað persónulega og krefjandi námsumhverfi sem skólinn býr beim“ (Háskólinn á Akureyri, 2012, bls. 6).

Pótt hvorki stjórnvöld né háskólarnir hafi sett fram skýra stefnu um að draga úr menntabili milli landshluta er svæðisbundnu framboði háskólamenntunar að verulegu leyti stýrt með fjárveitingum ríkisvaldsins. Samkvæmt fjárlagafrumvarpi ársins 2018 stunda pannig nám við háskólana í Reykjavík 84\% allra greiddra ársnema, 90\% ársnema í reikniflokki verkfræði og allir greiddir ársnemar í reikniflokkum á borð við læknisfræði, tölvunarfræði, stærðfræði og hönnunar- og listgreinar (Alpingi, 2017). Utan höfuðborgarsvæðisins býr priðjungur landsmanna og fjórðungur háskólamenntaðra landsmanna. Hins vegar stunda aðeins 16\% greiddra ársnema nám við háskóla utan höfuðborgarsvæðisins. 
Á næstu árum munu tækniframfarir umbylta háskólanámi um allan heim og rjúfa pá fjarlægðarvernd sem Háskóli Íslands hefur notið gagnvart öđrum löndum frá 1911 og landsbyggðaháskólarnir hafa notið gagnvart Reykjavík frá lokum tuttugustu aldar. Pað verður pví nauðsynlegt að skilgreina hlutverk íslenskra háskóla með hliðsjón af breyttum aðstæðum. Sé pað sérstakt markmið að hækka menntunarstig í öllum landshlutum og draga úr menntabili milli Reykjavíkur og annarra landshluta parf að skilgreina slík markmið með skýrum hætti og ákveða hvort pað skuli vera hlutverk allra háskóla eða sérstakt verkefni peirra háskóla sem staðsettir eru utan Reykjavíkur.

\section{University location and the regional gap in university education}

For centuries, the University of Copenhagen was the primary institution of higher education for Icelandic students. The establishment of the University of Iceland in 1911 transformed the structure of educational opportunities in Iceland and allowed prospective students in Reykjavík and adjacent areas the opportunity to live and study at home. In other regions of Iceland, however, university students continued to leave their home communities for study and only a minority of those students returned after graduation. As a result, there is a considerable gap between educational levels in the Reykavík capital area and other regions of Iceland.

In the period 1987-2008 several universities were founded, merged and renamed in Iceland. In the capital area, the private Reykjavík University and the Academy of Arts were established on the basis of earlier institutions, while the University of Education was merged with the University of Iceland. Outside the capital area, the University of Akureyri was established in northern Iceland, Bifröst University in the southwest and two agricultural schools in the north and southwest became universities. However, the public University of Iceland continues to be the largest institution of higher education with about $68 \%$ of all university students in the country.

The proportion of residents with a university degree differs substantially between the Reykjavík capital area and other regions of Iceland. This regional education gap can in part be traced to more diverse educational opportunities in the capital area, but various other economic, social, cultural and geographical factors are also important. Research has thus shown that the geographical location of universities can have a substantial effect on the residential choices of university graduates. This research focuses on the impact of Icelandic universities on levels of university education and the education gap between different regions of the country.

The regional impact of Icelandic universities is assessed on the basis of census data and survey results. About $28 \%$ of capital area residents and $12-14 \%$ of other residents graduated from universities in Reykjavík. The proportion of graduates from regional universities is highest $13 \%$ in Akureyri and $7 \%$ in other northern areas. A substantial majority of university graduates are from the University of Iceland. The proportion of University of Iceland graduates is highest in the capital area but lowest in Akureyri where a similar proportion graduated from the University of Akureyri.

In the capital area and the surrounding exurban regions, Reykjavík University has the second largest share of university graduates, while the University of Akureyri has the second largest share in the northern regions. A substantial majority of graduates from universities in Reykjavík and from Bifröst University reside in the capital area but graduates from other universities are more dispersed. Graduates from the University of Akureyri are roughly equally divided between the capital area, Akureyri and other regions. Graduates from the regional universities are more likely to live outside the capital area but the main impact on educational levels is found with respect to the University of Akureyri, in Akureyri and other northern regions. 
Future research should examine the careers of graduates from different universities and the extent to which they are employed in their fields of study. The employment of graduates from universities in Reykjavík and other regions should in particular be evaluated in the context of regional labour market differences. Conversely, the economic and social impact of restricted educational programmes at regional universities on local communities should be examined in more depth.

Neither the government nor the Icelandic universities have formed an explicit policy of decreasing the education gap between the Reykjavík capital area and other regions of the country. Nevertheless, regional differences in the supply of university programmes are to a considerable degree determined by government funding. Larger and more comprehensive programmes at regional universities would be the quickest way to raise educational levels outside the capital area.

Key words: Universities, educational levels, educational gap, region.

\section{Um höfund}

Dóroddur Bjarnason (thoroddur@unak.is) er prófessor í félagsfræði við félagsvísindaog lagadeild Háskólans á Akureyri. Hann lauk doktorsprófi frá University of Notre Dame í Bandaríkjunum, meistaraprófi frá University of Essex í Englandi og bakkalárprófi frá Háskóla Íslands. Rannsóknir hans eru einkum á sviði byggðafræði og beinast sérstaklega að búsetupróun og búferlaflutningum.

\section{About the author}

Thoroddur Bjarnason (thoroddur@unak.is) is Professor of Sociology at the Department of Social Sciences and Law at the University of Akureyri in Northern Iceland. He completed his PhD from the University of Notre Dame in the United States, his MA from the University of Essex in England and his BA from the University of Iceland. His research is primarily in the field of regional development and focuses in particular on migration and demographic trends.

\section{Heimildir}

A.P.H. (1985, 17. október). Ég er kominn hingað í læri. DV. Sótt 20. september 2017 af http:// timarit.is/files/19871136.pdf

Abel, J. R. og Deitz, R. (2012). Do colleges and universities increase their region's human capital? Journal of Economic Geography, 12(3), 667-691. doi.org/10.1093/jeg/lbr020

Alpingi. (2017). Fylgirit með frumvarpi til fjárlaga fyrir árið 2018. Sótt 25. september 2017 af https:// www.stjornarradid.is/lisalib/getfile.aspx?itemid=9b50f078-97bc-11e7-941c-005056bc4d74

Andersson, R., Quigley, J. M. og Wilhelmson, M. (2004). University decentralization as regional policy:The Swedish experiment. Journal of Economic Geography, 4(1), 37-388. doi.org/10.1093/ jnlecg/lbh031

Andersson, R., Quigley, J. M. og Wilhelmsson, M. (2009). Urbanization, productivity, and innovation: Evidence from investment in higher education. Journal of Urban Economics, 66(1), 2-15. doi. org/10.1016/j.jue.2009.02.004

Anna Guðrún Edvardsdóttir. (2016). The interaction of the knowledge society and rural development in Iceland and Scotland (óbirt doktorsritgerð). Háskóli Íslands, Reykjavík. 
Arbo, P. og Eskelinen, H. (2003). The role of small, comprehensive universities in regional economic development: Experiences from two Nordic cases. Ritgerð lögð fram á ráðstefnunni 43rd ERSA Congress, Jyväskyla, 27-30 ágúst 2003. Sótt 23. júní 2016 af https://www.jyu.fi/ersa2003/cdrom/papers/530.pdf

Á.M. (1985, 12. júní). Ráđstefna um háskólanám á Akureyri: Staðurinn er hér - stundin nú“. Dagur. Sótt 23. september 2017 af http://timarit.is/files/19136293.pdf

Árni Sæberg. (1988, 17. janúar). Tölvuháskóli Verzlunarskólans settur í fyrsta sinn. Morgunblaðið. Sótt 22. ágúst af http://www.mbl.is/greinasafn/grein/9915/

B. P. (2014, 4. desember). Barist fyrir auknu framlagi til HA. Akureyri vikublað. Sótt 19. september 2017 af http://timarit.is/files/34426791.pdf

Bjarni E. Guðleifsson. (1985, 20. nóvember). Háskólinn á Akureyri. Dagur. Sótt 11. september 2017 af http://timarit.is/files/19134797.pdf

Blackwell, M., Cobb, S. og Weinberg, D. (2002). The economic impact of educational institutions: Issues and methodology. Economic Development Quarterly, 16(1), 88-95. doi. org/10.1177/0891242402016001009

Bragi Guðmundsson. (2012). Háskóli verður til. Í Bragi Guðmundsson (ritstjóri), Háskólinn á Akureyri 1987-2012: Afmæelisrit (bls. 11-34). Akureyri:Völuspá og Háskólinn á Akureyri.

Börkur Hansen. (2005). Háskólar á Íslandi: Frá sundurgreiningu til samhæfingar. Uppeldi og menntun, $14,125-129$

Chatterton, P. (2000). The cultural role of universities in the community: Revisiting the university-community debate. Environment and Planning A, 32(1), 165-181. doi.org/10.1068/a3243

Chawinga,W. D. og Zozie, P.A. (2016). Increasing Access to higher education through open and distance learning: Empirical findings from Mzuzu university, Malawi. International Review of Research in Open and Distrubuted Learning, 17(4), 1-20. doi.org/10.19173/irrodl.v17i4.2409

Corcoran, J., Faggian, A. og McCann, P. (2010). Human capital in remote and rural Australia:The role of graduate migration. Growth and Change, 41(2), 192-220. https://doi.org/10.1111/j.14682257.2010.00525.x

Eyping. (2011). Fundargerð - Skýrsla stjórnar 2011. Sótt 18. september 2017 af https://www.eything. is/is/fundargerdir-1/adalfundir/fundargerd-skyrsla-stjornar-07-10-2011

Frenette, M. (2009). Do universities benefit local youth? Evidence from the creation of new universities. Economics of Education Review, 28(3), 318-328. doi.org/10.1016/j.econedurev.2008.04.004

G.S. (1985a, 22. febrúar). Mennt er máttur. Dagur. Sótt 1. september 2017 af http://timarit.is/ files/19131688.pdf

G.S. (1985b, 26. október). Samstaða norðanmanna um Háskóla á Akureyri er mikilvæg. Dagur. Sótt 11. september 2017 af http://timarit.is/files/19133929.pdf

Gillborn, D., Demack, S., Rollock, N. og Warmington, P. (2017). Moving the goalposts: Education policy and 25 years of the Black/White achievement gap. British Educational Research Journal, 43(5), 848-874. doi.org/10.1002/berj.3297

Gottlieb, P.D. og Joseph, G. (2006). College-to-work migration of technology graduates and holders of doctorates within the United States. Journal of Regional Science, 46(4), 627-659. doi.org/10.1111/ j.1467-9787.2006.00471.x

Gottlieb, P.D. og Fogarty, M. (2003). Educational attainment and metropolitan growth. Economic Development Quarterly, 17(4), 325-336. doi.org/10.1177/0891242403257274

Guðmundur Hálfdanarson. (2011). Embættismannaskólinn 1911-1961. Í Gunnar Karlsson (ritstjóri), Aldarsaga Háskóla Íslands 1911-2011 (bls. 17-295). Háskólaútgáfan: Reykjavík.

Gunasekara, C. (2006). Reframing the role of universities in the development of regional innovation systems. The Journal of Technology Transfer, 31(1), 101-113. doi.org/10.1007/s10961-005-5016-4 
Gunnar Karlsson (ritstj.) (2011). Aldarsaga Háskóla Íslands 1911-2011. Háskólaútgáfan: Reykjavík.

Gyða Jóhannsdóttir. (2008). Hvað einkennir próun háskóla? Í Rannsóknir í félagsvísindum IX (bls. 719-30). Reykjavík: Félagsvísindastofnun.

Haapanen, M. og Tervo, H. (2012). Migration of the highly educated: Evidence from residence spells of university graduates. Journal of Regional Science, 52(4), 587-605. https://doi.org/10.1111/j.14679787.2011.00745.x

Hagstofa Íslands. (2017a). Skráðir nemendur á háskóla- og doktorsstigi eftir skólum, tegund náms og kyni 2007-2014. Sótt 1. ágúst 2017 af https://hagstofa.is/talnaefni/samfelag/menntun/haskolastig/

Hagstofa Íslands. (2017b). Mannfjöldi eftir talningarsvæðum, menntunarstigi og aldri 31. des. 2011. Sótt 1. ágúst 2017 af https://hagstofa.is/talnaefni/ibuar/manntal/manntal-2011/

Halldór Blöndal. (1986, 30. maí).Við erum að byggja upp háskólanám á Akureyri. Morgunblaðið. Sótt 1. september 2017 af http://timarit.is/files/17405113.pdf

Háskólarád H.A. (2009, maí). Afstaða háskólaráđs til sameiningar í háskólakerfinu. Fréttatilkynning frá Háskólanum á Akureyri. Sótt 18. september 2017 af http://www.unak.is/is/frettir/afstada_haskolarads_til_sameiningar_i_haskolakerfinu

Háskóli Íslands. (2016a, september). Háskóli Íslands áfram í hópi 250 bestu háskóla í heimi. Fréttatilkynning frá Háskóla Íslands. Sótt 19. september 2017 af https://www.hi.is/frettir/haskoli_islands_afram_i_hopi_250_bestu_haskola_i_heimiHáskóli Íslands. (2016b). Stefna Háskóla Íslands 2016-2021. Sótt 25. september 2017 af https://www.hi.is/haskolinn/hi21_stefna_haskola_islands_2016_2021

Háskólinn á Akureyri. (2012). Stefna Háskólans á Akureyri 2012-2017. Sótt 25. september 2017 af http://www.unak.is/static/files/Stjornsysla_stefnumal/HA_Stefna2012-2017_www.pdf

Háskólinn á Bifröst. (2012). Stefna Háskólans á Bifröst. Sótt 25. september 2017 af http://www. bifrost.is/Files/Skra_0060617.pdf

Háskólinn á Hólum. (2016). Stefna Háskólans á Hólum 2016-2020. Sótt 25. september 2017 af http://www.holar.is/sites/holar.is/files/images/stefna_holaskola_2016-2020_21okt.pdf

Háskólinn í Reykjavík. (2017). Stefna Háskólans í Reykjavík. Sótt 25. september 2017 af https:// www.ru.is/skipulag/stefnur/hr/

Hoare, A. og Corver, M. (2010). The regional geography of new young graduate labour in the UK. Regional Studies, 44(4), 477-494. https://doi.org/10.1080/00343400902736543

Ingi Freyr Vilhjálmsson. (2013, 19. júlí). Stinga parf á háskólabólunni. DV. Sótt 17. september 2017 af http://www.dv.is/leidari/2013/7/19/stinga-tharf-haskolabolunni/

Ingi Rúnar Eðvardsson. (2001). University education and residential trends in Iceland. Scandinavian Journal of Educational Research, 45(3), 249-268. doi.org/10.1080/00313830120074198

Ingi Rúnar Eðvarðsson. (2014). A small university and knowledge-based development: A case of Northern Iceland. Journal of Knowledge-based Development, 5(2), 131-151.https://doi.org/10.1504/ IJKBD.2014.063990

Ingibjörg Einarsdóttir. (2010, 8. nóvember). Sameining háskóla frá sjónarhorni íbúa á Bifröst. Visir. Sótt 16. september 2017 af http://www.visir.is/g/2010563211580

Ingvar Gíslason. (1985, 19. júní). Háskóli á Akureyri er pólitísk ákvörðun. Dagur. Sótt 11. september 2017 af http://timarit.is/files/19136410.pdf

Jason Már Bergsteinsson, Ingi Rúnar Eðvarðsson og Guðmundur Kristján Óskarsson. (2017). Ofmenntun á íslenskum vinnumarkaði: Staða meðal háskólamenntaðs fólks. Íslenska pjóðfélagið, 8, 5-22. http://www.thjodfelagid.is/index.php/Th/article/view/109/pdf

Jón Bjarnason. (2013, 12. desember). Blóðtaka fyrir Borgfirðinga. Skessuhorn. Sótt 16. september 2017 af http://skessuhorn.rat.nepal.is/skessuhorn/adsendar-greinar/nr/182820/ 
Jón Bragi Bjarnason. (1989). Umræða um fyrirspurn til forsætisráðherra um aukna valddreifingu og flutning stofnana út í héruð. Dingfundur Alpingis, 7. desember 1989, sótt 16. september 2017 af http://www.althingi.is/altext/112/r1/1093.html

Jón Gunnar Grjetarsson. (1987, 17. september). Grun(n)laus háskóli? Háskólinn á Akureyri „,byggdapólitík" til að fá menntamenn nordur? Helgarpósturinn. Sótt 30. ágúst 2017 af http://timarit. is/files/9713439.pdf

Jón Dorkelsson. (1891). Um háskóla á Íslandi. Sunnanfari, 1, 28-33. Sótt 15. ágúst 2017 af http:// timarit.is/files/9713439.pdf

Kári Stefánsson. (2011, 16. janúar). Reisa albýðuhallir í austur-pýskum stíl. Morgunblaðið. Sótt 17. september 2017 af http://timarit.is/files/25656318.pdf

Klesment, M. og van Bavel,J. (2017). The reversal of the gender gap in education, motherhood, and women as main earners in Europe. European Sociological Review, 33(3), 465-481. doi.org/10.1093/ esr/jcw063

Kolfinna Jóhannesdóttir og Vífill Karlsson. (2010). Áhrif af háskólastarfsemi á samfélag og efnahag í Borgarbyggð. Borgarnes: Samtök sveitarfélaga á Vesturlandi. Sótt 1. september 2017 af http://ssv. is/Files/Skra_0069200.pdf

Landbúnaðarháskóli Íslands. (2008). Stefna Landbúnaðarháskóla Íslands 2009-13. Sótt 25. september 2017 af http://www.lbhi.is/sites/default/files/gogn/vidhengi/stefna_lbhi_18_desember_2008_ lokautgafa3_.pdf

Lehmann, M., Christensen, P., Thrane, M. og Jorgensen, T. H. (2009). University engagement and regional sustainability initiatives: some Danish experiences. Journal of Cleaner Production, 17(12), 1067-1074. doi.org/10.1016/j.jclepro.2009.03.013

Listaháskóli Íslands. (2017). Stefna og markmið. Sótt 25. september 2017 af http://www.lhi.is/stefna-og-markmid

Liu,Y., Green, A. og Pensiero, N. (2016). Expansion of higher education and inequality of opportunities: a cross-national analysis. Journal of Higher Education Policy and Management, 38(3), 242-263. doi.org/10.1080/1360080X.2016.1174407

Loftur Guttormsson (ritstjóri). (2008). Almenningsfreessla á Íslandi I: Skólahald í bae og sveit 1880-1945. Háskólaútgáfan.

Lög um háskóla, nr. 136/1997.

Lög um háskóla, nr. 63/2006.

Lög um Háskólann á Akureyri, nr. 18/1988.

Magnús B. Jónsson. (2013, 21. nóvember). Framtíð Landbúnaðarháskóla Íslands. Morgunblaðið. Sótt 19. september 2017 af http://www.mbl.is/greinasafn/grein/1488211/

Magnús Guðmundsson. (2011). Rannsóknarháskólinn 1990-2011. Í Gunnar Karlsson (ritstjóri), Aldarsaga Háskóla Îslands 1911-2011 (bls. 533-779). Háskólaútgáfan: Reykjavík.

Maiga, H. L. (1983). The Education Gap: A hard look at the plight of the world's rural areas. Unesco Courier, 5, 24-29.

Mennta- og menningarmálaráðuneytið. (2009a). Education, Research and Innovation policy:A new direction for Iceland. Sótt 18. september 2017 af https://www.stjornarradid.is/media/menntamalaraduneyti-media/media/MRN-pdf/Education,_research_and_innovation_policy._Skyrsla_erlendrar_serfradinefndar_mai_2009.pdf

Mennta- og menningarmálaráđuneytið. (2009b). Stefna í menntun, vísindum og nýsköpun: Ný stefna fyrir Ísland. Sótt 18. september 2017 af https://www.stjornarradid.is/media/menntamalaraduneyti-media/media/MRN-pdf/Stefna_i_menntun,_visindum_og_nyskopun.pdf

Mennta- og menningarmálaráðuneytið. (2015a). Háskólar og vísindi á Íslandi 2015: Staða og próun. Reykjavík: Mennta- og menningarmálaráðuneytið. 
Mennta- og menningarmálaráđuneytið. (2015b,janúar). Um stöðu háskóla og umræður um sameiningu peirra. Fréttatilkynning mennta- og menningarmálaráđuneytisins. Sótt 19. september 2017 af https://www.stjornarradid.is/efst-a-baugi/frettir/stok-frett/2015/01/23/Um-stodu-haskola-og-umraedur-umsameiningu-theirra/

Menntamálaráđuneytið. (1984). Álit nefndar sem menntamálaráðherra skipaði 27. maí 1982 til pess að gera tillögur um hvernig vinna megi að bví að efla Akureyri sem miðstöð mennta og vísinda utan höfuðborgarinnar. Reykjavík: Menntamálaráđuneytið.

Muhirwa,J. M. (2012). Funnelling talents back to the Source: Can distance education help to mitigate the fallouts of brain drain in sub-Saharan Africa? Diversities, 14, 45-62.

Nilsson, J. E. (ritstjóri). (2006). The Role of Universities in Regional Innovation Systems - A Nordic Perspective. Kaupmannahöfn: Copenhagen Business School Press.

NordForsk. (2017). Comparing research at Nordic higher education institutions using bibliometric indicators: Covering the years 1999-2014. Sótt 17. september 2017 af https://www.nordforsk.org/en/ publications/publications_container/comparing-research-at-nordic-higher-education-institutions-using-bibliometric-indicators-covering-the-years-1999-2014

OECD. (2015). E-learning in Higher Education in Latin America. Paris: OECD Publishing.

Rannís. (2017a). Gæðarád íslenskra háskóla. Sótt 11. september 2017 af https://www.rannis.is/ starfsemi/gaedarad/

Rannís. (2017b). Quality Enhancement Framework Handbook (2. útgáfa). Sótt 11. september 2017 af https://en.rannis.is/media/gaedarad/Final-for-publication-14-3-2017.pdf

Rennie, F., Jóhannesdóttir, S. og Kristinsdóttir, S. (2011). Re-thinking sustainable education systems in Iceland:The net-university project. International Review of Research in Open and Distance Learning, 12(4), 88-105. doi.org/10.19173/irrodl.v12i4.871

Ritstjórn. (2009, 2. október). Háskólinn í Reykjavík vill samvinnu en ekki sameiningu við Háskóla Íslands. Viðskiptablaðið. Sótt 19. september 2017 af http://www.vb.is/frettir/haskolinn-i-reykjavik-vill-samvinnu-en-ekki-samein/4303

RúnarVilhjálmsson. (2005). Gæðavandi íslenskra háskóla. Uppeldi og menntun, 14, 141-150.

RÚV. (2009). Sameining skilar mestum sparnaði. RÚV, 21. júlí 2013. Sótt 20. september 2017 af http://www.ruv.is/frett/sameining-skilar-mestum-sparnadi

RÚV. (2013a). Aðrir möguleikar en sameining HÍ og HR. RÚV, 25. júlí 2013. Sótt 19. september 2017 af http://www.ruv.is/frett/adrir-moguleikar-en-sameining-hi-og-hr

RÚV. (2013b). Sameining háskóla í undirbúningi. RÚV, 20. júlí 2013. Sótt 19. september 2017 af http://www.ruv.is/frett/sameining-haskola-i-undirbuningi

RÚV. (2013c). Sameining við HÍ heppilegust. RÚV, 24. nóvember, 2013. Sótt 19. september 2017 af http://www.ruv.is/frett/sameining-vid-hi-heppilegust

RÚV. (2014). Hætt við sameiningu HÍ og LBHÍ, RÚV, 23. mars 2014. Sótt 11. september 2017 af http://www.ruv.is/frett/haett-vid-sameiningu-hi-og-lbhi

RÚV. (2015). Bifröst vill ekki nauðungarhjónaband. RÚV, 7. febrúar 2015. Sótt 19. september 2017 af http://www.ruv.is/frett/bifrost-vill-ekki-i-naudungarhjonaband

Scott, T., Menzies, C., Chenard, G. og Spence, M. (2013). Bridging the gap: Innovative approaches to continuing education in rural, remote, and isolated First Nation communities. Seminars in Dialysis, 26(2), 164-168. doi.org/10.1111/sdi.12058

S. H.Á. (2009, 12. september). Stóru háskólarnir ræða um samstarf. Fréttablaðið. Sótt 19. september 2017 af http://timarit.is/files/13134109.pdf

Sindri Sigurgeirsson. (2013, 31. október). Bændur vilja standa vörð um sjálfstæði landbúnaðarháskólanna. Bæendablaðið. 
Skagfirðingur. (2012, 2. apríl). Hólaskóli sameinaður Háskólanum á Akureyri. Skagfirðingur. Sótt 16. september 2017 af https://skagfirdingur.wordpress.com/2012/04/02/holaskoli-sameinadur-haskolanum-a-akureyri/

Skessuhorn. (2013, 26. nóvember). Skora á ráđherra að standa vörð um háskólana í Borgarbyggð. Skessuhorn.

Skessuhorn. (2014, 12. september). Ráðherra á pólitísku blindskeri varðandi sameiningu L.B.H.Í.og HÍ. Skessuhorn. Sótt 19. september 2017 af http://skessuhorn.rat.nepal.is/frettir/nr/189788/ Sótt 25. september 2017 af https://www.althingi.is/lagasafn/pdf/134/2006063.pdf

Tam,T. og Jiang,J. (2015). Divergent urban-rural trends in college attendance: State policy bias and structural exclusion in China. Sociology of Education, 88(2), 160-180. doi.org/10.1177/0038040715574779

Tillaga til pingsályktunar um framtíðarstaðsetningu skóla og eflingu Akureyrar sem skólabæjar nr. 48/1964. Sótt 11. september 2017 af: http://www.althingi.is/altext/85/s/pdf/0053.pdf

Tomaney, J. og Wray, F. (2011). The university and the region: An Australian perspective. International Journal of Urban and Regional Research, 35(5), 913-931. doi.org/10.1111/j.1468-2427.2011.01020.x

Vífill Karlsson og Magnús B. Jónsson. (2013). Hvers vegna cettum við að hafa marga háskóla og dreift háskólanám? Borgarnes: Samtök sveitarfélaga áVesturlandi. Sótt 1. september 2017 af http://ssv. is/wp-content/uploads/2016/09/Skra_0066054.pdf

Vísindafélag Norðlendinga. (1985, 12. desember). Akureyrarháskólinn fái fjárveitingu á næsta ári. NT. Sótt 20. september 2017 af http://timarit.is/files/14515001.pdf

Waldorf, B. S. (2009). Is human capital accumulation a self-propelling process? Comparing educational attainment levels of movers and stayers. Annals of Regional Science, 43(2), 323-344. doi. org/10.1007/s00168-008-0225-z

Winters, J.V. (2011). Human capital and population growth in nonmetropolitan U.S. Counties: The importance of college student migration. Economic Development Quarterly, 25(4), 353-365. doi. org/10.1177/0891242411418221

Dingsályktun um dreifingu menntastofnana, áætlun um skólapörf og eflingu Akureyrar sem miðstöðvar mennta og vísinda utan höfuðborgarinnar. Sampykkt á 92. löggjafarpingi 1971-1972. Sótt 11. september 2017 af: http://www.althingi.is/altext/92/s/0942.html

Dingskjal nr. 150/2011-2012. Fyrirspurn til mennta- og menningarmálaráðherra um sjálfstæði Háskólans á Akureyri. Frá Birki Jóni Jónssyni. Sótt 16. september 2017 af http://www.althingi. is/altext/140/11/114174426.sgml

D.J. og S. H.A. (2010, 13. september). Bifröst og H.R. ræða sameiningu skólana. Fréttablaðið. Sótt 19. september 2017 af http://timarit.is/files/24683911.pdf

Dorgerður Katrín Gunnarsdóttir. (2012, 14. febrúar). Sameinum háskóla. Visir. Sótt 19. september 2017 af http://visir.staging.is/g/2012702149993/sameinum-haskola

Dorkell Jóhannesson. (2004, 28. mars). Háskólar - Rannsóknaháskólar. Morgunblaðið. Sótt 17. september 2017 af http://timarit.is/files/7989231.pdf

Dóroddur Bjarnason og Brynhildur Dórarinsdóttir. (2018). The effects of regional and distance education on the supply of qualified teachers in rural Iceland. Sociologia Ruralis, http://onlinelibrary. wiley.com/doi/10.1111/soru.12185/epdf

Dóroddur Bjarnason og Ingi Rúnar Eðvarðsson. (2017). University pathways of urban and rural migration in Iceland. Journal of Rural Studies, 54, 244-254. doi.org/10.1016/j.jrurstud.2017.07.001

Póroddur Bjarnason, Ingi Rúnar Eđvarðsson, Ingólfur Arnarson, Skúli Skúlason og Kolbrún Ósk Baldursdóttir. (2016). Svæðisbundin áhrif íslenskra háskóla. Uppeldi og menntun, 25, 265-287.

Puríður J. Jóhannsdóttir. (2010). Teacher education and school-based distance learning: individual and systemic development in schools and a teacher education programme (óbirt doktorsritgerð). Háskóli Íslands. 
Örn Arnarson. (2010, 8. nóvember). Háskólastarfá Bifröst legðist af. Morgunblaðið. Sótt 20. september af http://timarit.is/files/25736614.pdf

Dóroddur Bjarnason. (2018).

Staðsetning í háskóla og menntabil í háskólamenntun.

Netla - Veftímarit um uppeldi og menntun. Menntavísindasvið Háskóla Íslands.

Sótt af http://netla.hi.is/greinar/2018/ryn/01.pdf

DOI: https://doi.org/10.24270/netla.2018.1 